Deconstructing the "Sanders Focus" and the "Sanders Phase": A Reply to Perttula Regarding the Taxonomy and Significance of the So-called Sanders Focus, or Sanders Phase, Pottery of Northeast Texas and Southeast Oklahoma

Frank F. Schambach

Arkansas Archaeological Survey

Follow this and additional works at: https://scholarworks.sfasu.edu/ita

Part of the American Material Culture Commons, Archaeological Anthropology Commons, Environmental Studies Commons, Other American Studies Commons, Other Arts and Humanities Commons, Other History of Art, Architecture, and Archaeology Commons, and the United States History Commons

Tell us how this article helped you.

This Article is brought to you for free and open access by the Center for Regional Heritage Research at SFA ScholarWorks. It has been accepted for inclusion in Index of Texas Archaeology: Open Access Gray Literature from the Lone Star State by an authorized editor of SFA ScholarWorks. For more information, please contact cdsscholarworks@sfasu.edu. 
Deconstructing the "Sanders Focus" and the "Sanders Phase": A Reply to Perttula Regarding the Taxonomy and Significance of the So-called Sanders Focus, or Sanders Phase, Pottery of Northeast Texas and Southeast Oklahoma

Creative Commons License

(c) (1) (9)

This work is licensed under a Creative Commons Attribution-NonCommercial 4.0 International License 
Volume $9(3 / 4)$

\title{
Deconstructing the "Sanders Focus" and the "Sanders Phase": A Reply to Perttula Regarding the Taxonomy and Significance of the So-called Sanders Focus, or Sanders Phase, Pottery of Northeast Texas and Southeast Oklahoma
}

\author{
Frank F. Schambach \\ Arkansas Archeological Survey
}

\section{Introduction}

Perttula (1997b) is correct in pointing out that there are numerical errors in a recently published table of mine (Schambach 1997a:Table 1). A revised version is presented here as Table 1. Although several of these errors are numerically large and might have caused problems had they gone uncorrected, Perttula is not correct in suggesting that they are "serious" in the sense that they have affected the conclusions I "reached based on the table," the insinuation being that they weaken my Sanders entrepot hypothesis. They do not. That hypothesis is part of the reinterpretation of the archeology and bioanthropology of the Arkansas Valley and the Red River Valley which I have been developing for more than eight years (Schambach 1990a, 1990b, 1991, 1993a, 1993b, 1994a, 1994b, 1994c, 1994d, 1995, 1996, 1997a, 1997b). It could hardly be weakened by errors in this table which is simply a compilation of the pottery of the five so-called Sanders focus/ phase types (Canton Incised, Sanders Engraved, Maxey Noded Redware, Monkstown Fingernail Impressed, and Sanders Plain) reported from the list of "sites with probable Sanders phase components" recently proffered by Bruseth, Wilson, and Perttula (1995: Table 1).

The conclusion (Schambach 1997a:2022) that is based on this table - that "Occurrences of bona fide specimens" of the "so-called Sanders focus types" at "southeast Oklahoma and northeast Texas sites other than Sanders are too infrequent and the types themselves too erratically represented to support the concept of a Sanders focus, or phase" - is not affected either. Limiting myself to pottery reportedly of the red-slipped fineware types Sanders Engraved, Maxey Noded Redware, and Sanders Plain, I stated (1997a:22) that the 23 sites on Bruseth, Wilson, and Perttula's list have yielded 
Table 1. "Sanders focus" pottery types reported from sites on Bruseth, Wilson, and Perttula's list of sites with "probable Sanders phase" components.

\begin{tabular}{|c|c|c|c|c|c|c|}
\hline Sites & Canton Incised & $\begin{array}{l}\text { Sanders } \\
\text { Engraved }\end{array}$ & $\begin{array}{l}\text { Maxey Noded } \\
\text { Redware }\end{array}$ & $\begin{array}{l}\text { Monkstown } \\
\text { Fingernail } \\
\text { Impressed } \\
\end{array}$ & Sanders Plain & $\begin{array}{l}\text { Total sherds, } \\
\text { all types }\end{array}$ \\
\hline A. C. Mackin & 1 & 0 & 1 & 0 & 28 & 2357 \\
\hline Baldwin & 2 & 0 & 5 & 0 & 39 & 1294 \\
\hline Beaver & 37 & 7 & 8 & 0 & 818 & 5347 \\
\hline Bell & 0 & 5 & 0 & 0 & 10 & 766 \\
\hline Clement & 0 & 0 & 0 & 0 & 0 & 0 \\
\hline Cook & 1 & 0 & 0 & 0 & 0 & 62 \\
\hline E. Johnson & 29 & 12,2 pots & 4 & 0 & 301,2 pots & 5690 \\
\hline Fasken & 0 & 0 & 0 & 0 & 0 & 0 \\
\hline Gregory & 10 & 0 & 0 & 0 & 15 & 430 \\
\hline Harling & 0 & 0 & 0 & 0 & 0 & 0 \\
\hline Hines & 9 & 4 & 0 & 0 & 0 & 1378 \\
\hline Holdeman & 8 pots & 1 pot & 12 pots & 0 & 0 & (255 pots) \\
\hline $\begin{array}{l}\text { Kaufman, E. } \\
\text { Md. }\end{array}$ & 4 & 1 & 0 & 0 & 15 & 1076 \\
\hline Mahaffey & 41,1 pot & 0 & 0 & 1 & 13 & 1502 \\
\hline Nelson & 83 & 0 & 3 & 0 & 61 & 598 \\
\hline Pat Boyd & 284 & 9 & 18 & 0 & 252 & 4668 \\
\hline Payne & 12 & 0 & 0 & 0 & 532 & 6676 \\
\hline Pine Creek & 0 & 0 & 0 & 0 & 10 & 505 \\
\hline Roitsch & 0 & 0 & 0 & 0 & 0 & 0 \\
\hline Spoonbill & 30 & 12,1 pot & 0 & 2 pots & 0 & 2584 \\
\hline Taddlock & 758 & 305 & 0 & 0 & 0 & 18,605 \\
\hline T. Moody & 0 & 0 & 0 & 0 & 0 & 0 \\
\hline Woods Md. & 0 & 0 & 0 & 0 & 0 & 2208 \\
\hline Yarbrough B & 126,1 pot & 45. I pot & 0 & 1 & 89,7 pots & 612 \\
\hline Totals & 1427,10 pots & 400,5 pots & 39.12 pots & 2,2 pots & 2183,9 pots & 56,358 \\
\hline $\begin{array}{l}\% \text { of } 1867 \\
\text { decorated sherds } \\
\text { reported }\end{array}$ & $76 \%$ & $21 \%$ & $2 \%$ & $.1 \%$ & & \\
\hline
\end{tabular}


"only 384 sherds and five pots identified as Sanders Engraved, 39 sherds and five pots identified as Maxey Noded Redware and 2215 sherds and nine pots identified as Sanders Plain." Thus, I observed that "only about $2.4 \%$ of all the pottery from them $(109,727$ sherds and 195 pots $)$ is reportedly of red slipped 'Sanders focus' types, not what I would call an abundant representation."

According to my corrected version ${ }^{1}$ of Table 1, these figures must be revised as follows. The reported totals are 400 (rather than 384) sherds and five pots for Sanders Engraved; 39 sherds and 12 (rather than 5) pots for Maxey Noded Redware; and 2183 (rather than 2215) sherds and nine pots for Sanders Plain. Not much different from my original figures.

There is, however, a large difference in the total number of sherds of all types reported from all sites, which is 56,358 rather than 109,727 . That error arose when I commingled two columns of figures while typing from the original handwritten draft of the table, thereby increasing by a factor of 10 each the totals for the Hines, Spoonbill, and Woods Mound sites. So my statement concerning the frequency of these three types at sites with so-called Sanders phase components must be modified to read "only about $4.6 \%$ of all the pottery from them $(56,358$ sherds and 255 pots) is reportedly of red slipped "Sanders focus" types."

Nevertheless, my conclusion that these types are too weakly and erratically represented at sites in southeast Oklahoma and northeast Texas to support the concept of a Sanders focus, or phase, is still valid. In this context the difference between $2.4 \%$ and $4.6 \%$ is insignificant; $4.6 \%$ is not "what I would call an abundant representation" of these types either. Nor do I think anyone else would. Neither is 7\%, which is the percentage of the 4051 sherds of all five so-called Sanders focus/ phase types reported from these sites. These pottery types are weakly represented at every site on Bruseth, Wilson and Perttula's list. Not surprisingly, they are no better represented at the 17 sites or parts of sites Perttula now (1997b:12-16) wants to add to it. At these (Table 2), the number of reported sherds of the types Sanders Engraved, Maxey Noded Redware and Sanders Plain (718) amounts to $4.8 \%$ of the 15,056 reported sherds of all types and the total for all five types (994) is 6.6\%.

Any Red River Valley Caddo phase as weakly and erratically represented ceramically as this - and bear in mind that ceramics of putative Sanders focus/phase types are the only putative Sanders focus/phase diagnostics reported for any of these 40 putative components - would have to be considered questionable. However, in the unusual case of the Sanders "focus," which is neither a focus nor a phase but an unconfirmed hypothesis that Alex D. Krieger invented to explain the Sanders mortuary assemblage this consistently weak representation is much more significant. It is proof that Krieger's hypothesis, hence also the Sanders focus, is invalid because it contradicts the basic tenet of that hypothesis, which is that the Sanders focus represents a unique, frontier manifestation of Caddo culture that devel- 
Table 2. So-called Sanders Phase pottery types reported from sites on Perttula's supplementary list of sites with "Sanders phase" components.

\begin{tabular}{|c|c|c|c|c|c|c|c|}
\hline Site & $\begin{array}{l}\text { Canton } \\
\text { Incised }\end{array}$ & $\begin{array}{l}\text { Sanders } \\
\text { Engraved }\end{array}$ & $\begin{array}{l}\text { Maxey } \\
\text { Noded } \\
\text { Redware } \\
\end{array}$ & $\begin{array}{l}\text { Monkstown } \\
\text { Fingernail } \\
\text { Impressed } \\
\end{array}$ & $\begin{array}{l}\text { Sanders } \\
\text { Plain }\end{array}$ & $\begin{array}{l}\text { Total } \\
\text { Sherds of } \\
\text { all types } \\
\end{array}$ & Reference \\
\hline 41WD117 & & & & & 1 pot & 26 & Perttula $1986: 482$ \\
\hline $41 \mathrm{WD} 145$ & & 1 & 1 & & 8 & 62 & Perttula $1986: 482$ \\
\hline 41 WD178 & 3 & & & & 3 & 17 & Perttula 1986:483 \\
\hline McKenzie Md. & 40 & 8 & & & & 1,044 & Granberry 1995 \\
\hline $\begin{array}{l}\text { Hurricane } \\
\text { Hill }\end{array}$ & 44 & 26 & 4 & & & 8127 & Perttula 1997:15 \\
\hline $\begin{array}{l}\text { Roitsch "youth } \\
\text { area" }\end{array}$ & "sherds" & "sherds" & 1 & & & 625 & Perttula 1997:12 \\
\hline $\begin{array}{l}\text { Roitsch "East } \\
\text { Mound" }\end{array}$ & 37 & "sherds" & & & & $?$ & Perttula 1997:13 \\
\hline 41RR305 & "sherds" & "sherds" & & & & 55 & Perttula 1997:12 \\
\hline Limerick & 37 & 8 & & & 520 & 1095 & Duffield 1961:86-90 \\
\hline 41RA65 & 7 & 3 & & & & 221 & Perttula 1997:13 \\
\hline $\begin{array}{l}\text { McCreight } \\
\text { Md., }\end{array}$ & 42 & & & & & 343 & Perttula 1997:13 \\
\hline Carlisle & $35+$ & 12 & 7 & & & 616 & Perttula 1997:13 \\
\hline $\begin{array}{l}\text { Williams } \\
(41 \mathrm{CP} 10)\end{array}$ & & & & & 2 pots & 50,15 pots & Thurmond 1990:146 \\
\hline $\begin{array}{l}\text { Watson } \\
(41 \mathrm{MX} 6)\end{array}$ & & $\begin{array}{l}2 \text { pots, } 5 \\
\text { sherds }\end{array}$ & & & & $\begin{array}{l}269 \\
8 \text { pots } \\
\end{array}$ & Thurmond 1990:175 \\
\hline $\begin{array}{l}\text { Keith } \\
(41 T T 11)\end{array}$ & 23 & 30 & & & 80 & 2112 & Thurmond 1990:184 \\
\hline Tigent & 7,1 pot & 2 & & & & 81,4 pots & Brown 1975 \\
\hline $\begin{array}{l}\text { Garrison } \\
\text { (41WD16) }\end{array}$ & 4 & & & & 1 & 313 & Thurmond 1990:213 \\
\hline Totals & $\begin{array}{l}276 \\
1 \text { pot } \\
\end{array}$ & $\begin{array}{l}94, \\
2 \text { pots } \\
\end{array}$ & 13 & 0 & $\begin{array}{l}611 \\
3 \text { pots } \\
\end{array}$ & $\begin{array}{l}15,056 \\
17 \text { pots } \\
\end{array}$ & \\
\hline
\end{tabular}

oped in response to environmental conditions peculiar to a small area in northeast Texas and southeast Oklahoma. If Kreiger's hypothesis were valid these types would be clearly and consistently the major ones rather than clearly and consistently the minor ones at virtually every so-called Sanders focus/phase site. 
Volume $9(3 / 4)$

\section{Deconstructing the Sanders Focus}

Defenders of the Sanders focus/phase may object that this is an oversimplification and misrepresentation of Krieger's work. The following review of the history of this peculiar concept will, I trust, show that it is not, and that the distribution of the five so-called Sanders focus/phase pottery types in northeast Texas and southeast Oklahoma does, indeed, refute his hypothesis.

The history of the Sanders focus concept begins with Krieger's unpublished (1941) first effort to interpret the Sanders mortuary assemblage, a manuscript titled The Pottery of the Sanders Farm, Lamar County. The interpretation he essayed there is similar to mine in that he thought it represented a movement of Mississippians into the Red River Valley. "The Sanders people," he wrote, "may have migrated into the region several centuries ago with certain pottery forms which they continued thereafter, but they appear to have received a number of pottery diffusions after arrival."

Then, because this was his first work in the Caddo area and he was inexperienced in Southeastern archeology ${ }^{2}$, he sent his manuscript to James B. Griffin for review. And Griffin, who was trying to stem the tide of usually spurious Mississippian migration and site unit intrusion hypotheses that was on the rise throughout the Southeast at that time (Smith 1984:21), disagreed. In a long letter (Griffin 1941) he replied: "It is unreasonable to believe that in this large and favorable area it is necessary to explain the fundamental cultural base as the result of a recent migration from the Mississippi Valley."

At that point, Krieger might better have stuck with his own interpretation since he was right about Sanders mortuary assemblage representing a movement of Mississippians into the Red River Valley, although wrong, perhaps hopelessly so, as to the scale, purpose and effects of that event which was - as I hypothesize not a mass migration but the establishment of an entrepot by a group of Mississippian traders. But he bowed to Griffin's judgement, thereby saddling himself with an impossible task: the transformation of the Sanders mortuary assemblage, which he had correctly identified as Mississippian, into something that could pass for a Red River Valley Caddo assemblage.

This he had to do despite what was as recognizable then as now as its locally unique burial pattern; despite the superabundance of shell beads, shell cups, and shell gorgets, unmatched then, as now, at other Red River Valley sites; despite his prescient recognition that the ceramic assemblage is fundamentally unlike any Red River Valley Caddo ceramic assemblage; despite the extraordinary number and variety of pots that he traced - with Griffin's (1941) blessing - to the Mississippi Valley (Krieger 1946:171 218, Newell and Krieger 1949:218-219); and despite the peculiar location of the site 
at, if not slightly beyond, the western limits of Caddo settlement in the Red River Valley.

In trying to do this, in trying to explain how a mortuary assemblage so unlike every known Caddo assemblage from the Red River Valley could nevertheless be a Caddo assemblage, he was drawn into two errors, one factual, the other methodological. First, he jumped to the conclusion that the Sanders site, located on the northeastern edge of the Blackland Prairie in northeast Texas (Figure 1), is on the edge of the Plains. Then, in a resort to environmental determinism for which he has never been taken to task, he reconceptualized the Sanders focus as a unique, western Caddo area focus representing a "frontier culture facing the open Plains country" (Krieger 1946:172, 213, Newell and Krieger 1949:218-219) with "components found in a narrow north-south belt on both sides of Red River, approximately on the border between eastern forest and open plains" (Krieger 1946:172). It was this position "on the western frontier of Southeastern 'Mississippian' culture, at the edge of the eastern forests and facing the rolling plains" that set it apart from the four other early Caddo foci recognized then: Alto, Haley, Gahagan, and Spiro. These were "found farther east, well within the forest-lands of eastern Oklahoma and Texas, western Arkansas, and northwestern Louisiana" (Krieger 1946:213).

Actually, neither the Sanders site, nor any of the other putative Sanders focus "components" that, in Krieger's view, occupied "a narrow north-south belt ... approximately on the border between eastern forest and open plains" are anywhere near the "open plains" (Krieger 1946:172), or the "rolling plains" (Krieger 1946:213), or "the open Plains country" (Newell and Krieger 1949:218), or "the Great Plains" (Suhm, et al. 1954:176). If they were, they would be more than a hundred miles to the west near Spanish Fort, Texas (Figure 1), beyond the western edge of the Blackland Prairie, beyond the north-south oriented band of oak-hickory savanna called the Eastern Cross Timbers, beyond the Grand Prairie, and beyond a second band of savanna called the Western Cross Timbers (Bastian 1966:1, Dillehay 1974:181, Fig.1, Fenneman 1938:102, Fig. 27, Webb 1981:30). ${ }^{3}$

None the less, because Krieger's hypothesis is based on the assumption that the local environment is the reason for the locally unique aspects of the Sanders mortuary assemblage, including the distinctive ceramic assemblage, it follows that the (hypothetically Caddoan) Sanders focus would have to be the only Red River Caddo focus/phase represented at practically every site with a putative "Sanders focus" component. If earlier, later, or contemporaneous components of any "other" foci or phases of Red River Caddo culture are consistently well represented at these sites as well then the hypothesis fails; geography could not be the reason the "Sanders focus" is, as Caddo area archeologists have been fond of repeating, "the most divergent of all Caddo foci" (Davis 1970:42, Newell and Krieger 1949: 218; Story et al. 1990:303; Suhm et al. 1954:176). 


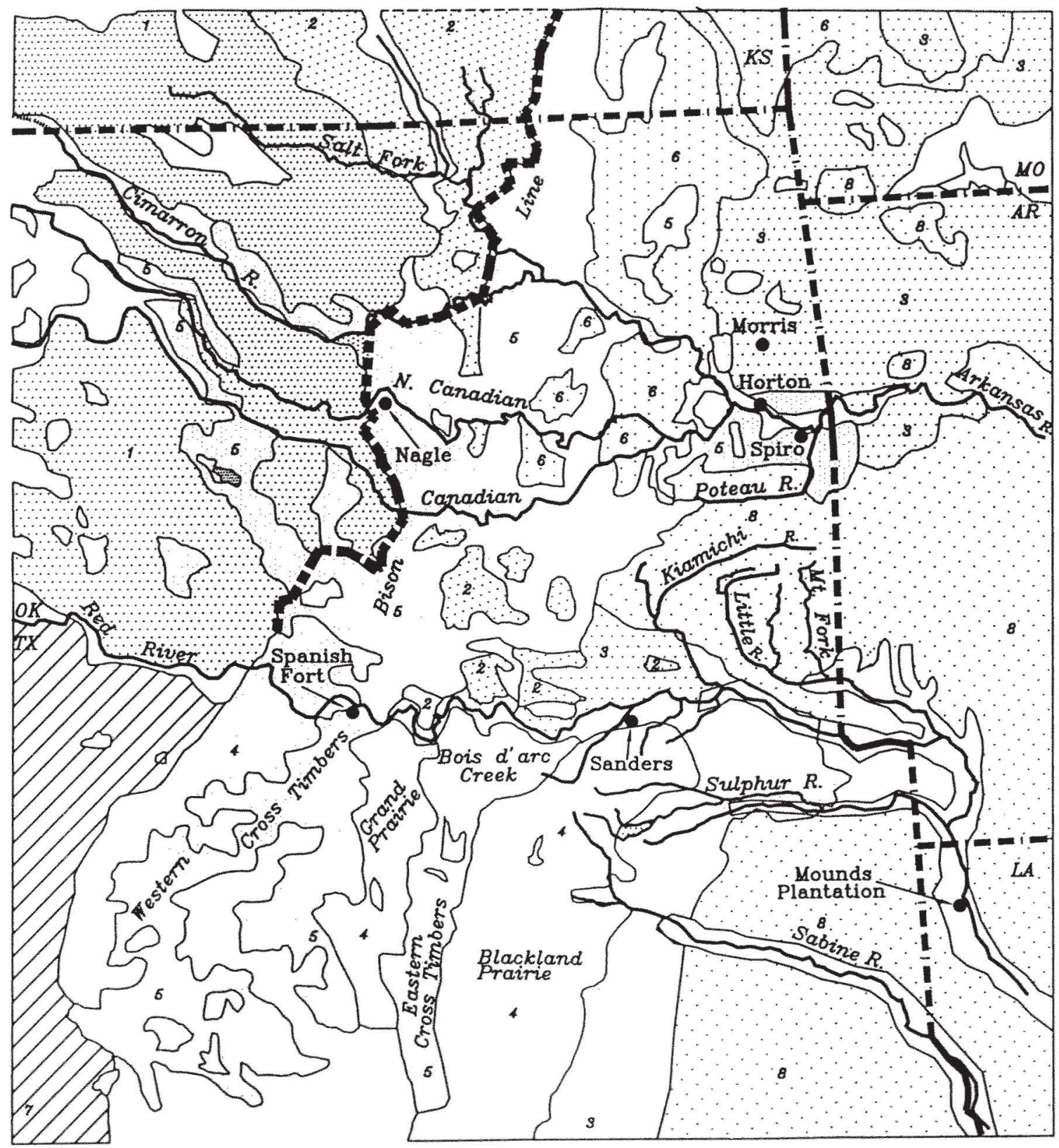

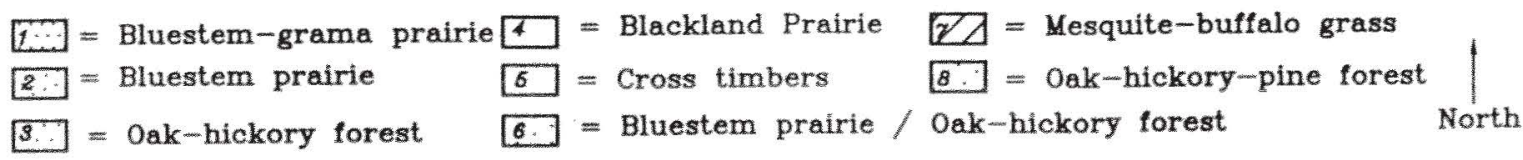
m. $=$ Bison Line

Figure 1. The location and biogeography of the Sanders site. 
And fail it does. The figures presented in Tables 1 and 2 show there are no sites at which so-called Sanders focus/phase pottery types come anywhere near dominating the collections. Components of various "other" foci/phases of Red River Valley Caddo culture have long been recognized at most of them and it is the ceramics of these that dominate. Thus Bruseth (1998:Tables 3-3 and 3-5) lists A. C. Mackin, Beaver, Bell, E. Johnson, Gregory, Holdeman, Mahaffey, and Roitsch as sites with "Formative Caddoan components" as well as "Sanders phase" components. And he lists Baldwin, Beaver, Bell, Clement, E. Johnson, Gregory, Holdeman, Pat Boyd, Pine Creek, and Roitsch, as sites with probable McCurtain phase components. The Cook and Nelson sites have long been considered the type sites for the informally defined "Nelson focus" (Bell and Baerreis 1951:48-53) and Rohrbaugh (1973:186193, Figs. 57-58) has assigned Cook to his early Caddo Apple phase. The Clement site is generally considered the type site for the McCurtain focus (Bell and Baerreis 1951:53, Flynn 1976:27, Wyckoff 1967a: 8). Gettys (1975:226) concluded that the Pine Creek site "represents a localized manifestation of the Hochatown complex in the Glover River area." And Wyckoff (1967b:66) concluded that all eight mounds at the Woods site are the contemporaneous remains of a McCurtain focus occupation.

So the corpus of virtually single component "Sanders focus/phase" sites representing a unique "frontier culture facing the open Plains country" (Krieger 1946: 172,213 ; Newell and Krieger 1949:218-
219) that Krieger's hypothesis requires does not exist. Nor are the sites attributed to the Sanders focus/phase distributed, as his hypothesis specifies, in the "narrow north-south belt on both sides of Red River" (actually, the border between the Blackland Prairie and the Oak-Hickory savannah of northeast Texas and southeast Oklahoma) that Krieger (1946:172) mistook for the "border between eastern forest and open plains." Except the Sanders site itself and the enigmatic Harling Mound, all the sites on Bruseth, Wilson, and Perttula's list are ensconced in woodland environments east of the Blackland Prairie (Figure 2), None of them are, as his hypothesis requires, in an environment "which is essentially a prairie rather than a forest" (Suhm et al. 1954:154).

So Krieger failed to do the impossible. He did not produce a valid hypothesis that explains why the Mississippian mortuary assemblage from the Sanders site was what Griffin thought it should be: a component of the "fundamental cultural base" in the Caddo area in the Red River Valley. Therefore, there is no Sanders focus, hence there is no viable explanation for the Sanders mortuary assemblage except mine (1993a:203-208), which is that is an intrusive, Spiro phase, Mississippian assemblage from the Arkansas Valley.

None of this should come as a surprise to Perttula and other latter day defenders of the Sanders focus/phase because I am not the first to question the validity of that taxon, nor am I the first to reject it. Forty years ago, Webb (1958:49-50) described it as "preliminary" and in need of "rounding 


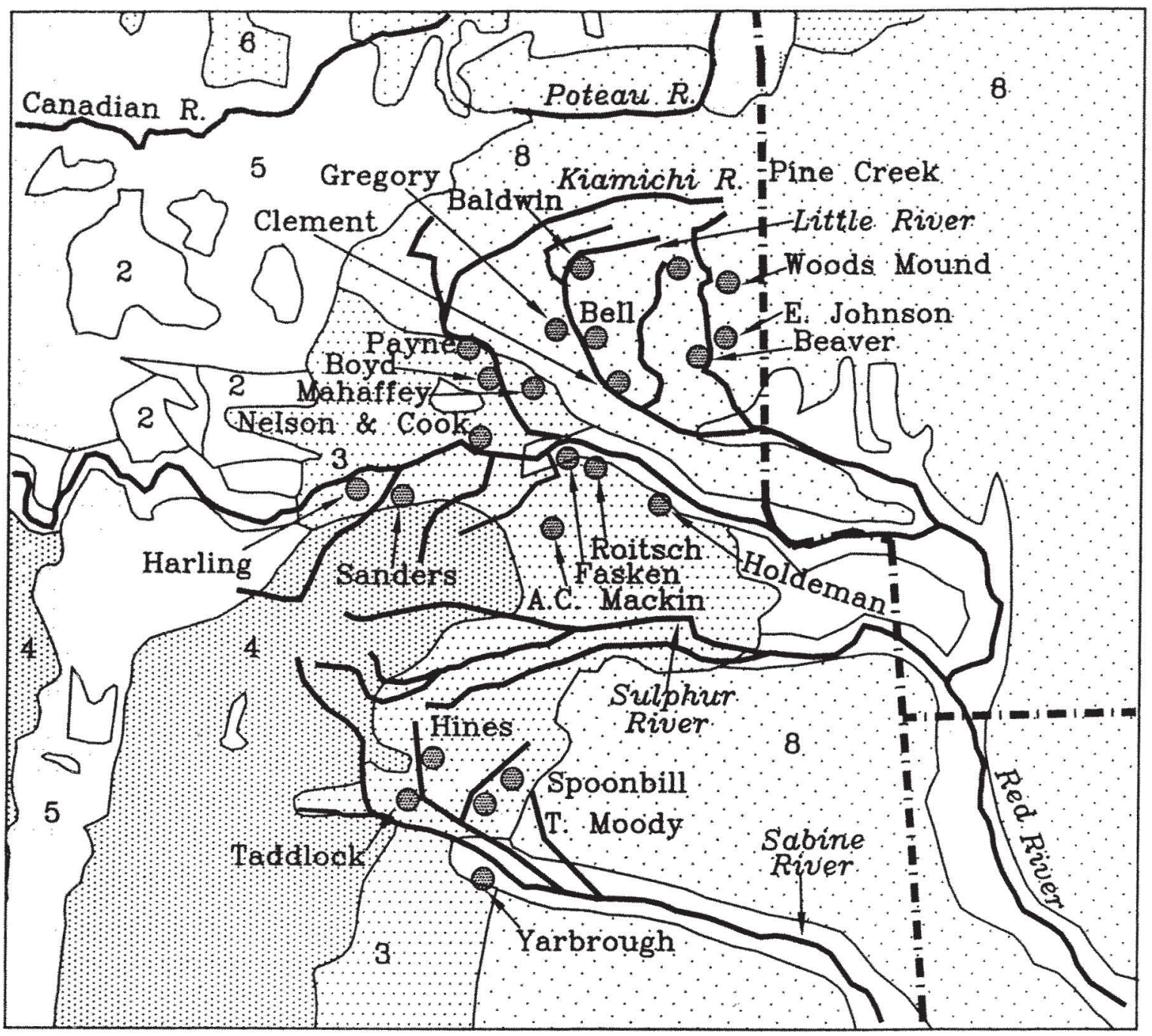

$1+2=$ Bluestem-grama prairie $5=$ Cross timbers

2 - Bluestem prairie $\quad 6:=$ Bluestem prairie / Oak-hickory forest

$3=$ Oak-hickory forest $8=0$ ok-hickory-pine forest

4 = Blackland prairie North

Figure 2. The distribution and biogeography of Bruseth, Wilson, and Perttula's sites with "probable Sanders phase components." 
out by studies of other sites," questioning in particular "whether other sites exhibit the combination of Plains traits (bison hunting, bison scapula hoes, 4-edged beveled knives, stone elbow pipes), Caddoan traits, and southern cult objects described for the Sanders site." The answer, as far as Caddo sites in the Red River Valley and adjacent uplands in northeast Texas and southeast Oklahoma are concerned, was no then, and it is still no. But many Spiro phase sites in the Arkansas Valley exhibit them (Schambach 1993a:197-199) which means they must be considered Spiro phase traits as well as Plains traits.

Twenty-three years later, Bruseth and Perttula (1981:6) raised essentially the same question - basically, the question of the validity of the Sanders site as the type site for the group of components generally classified as Sanders focus-by remarking: "Unfortunately, this focus was defined on the basis of a single, and apparently rather unique, site (i.e., Sanders Site). No site excavated since has included all of the cultural traits recognized at the type site." However they failed to consider the implications of what they were saying. If a "site" (actually, it is the Sanders mortuary assemblage we are talking about, not the Sanders site) is unique it cannot be the type site for a focus, which in theory is always a multi-component unit, or for a multi-component phase. (Willey and Phillips 1962:21-22).

In 1984, Brown (1984:262), whose earlier study (Brown 1971:145-171) of the pottery from Spiro and observations on the pottery from Sanders made clear that most of the pots from the graves at Sanders are Spiroan by type and probably by derivation as well (Schambach 1993a:203204), summarily wrote off the Sanders focus as a taxonomic unit, referring to it and the supposedly related "Nelson focus" in southeastern Oklahoma as "regional variants of the Spiro phase." That is close to my interpretation of both of these taxa. ${ }^{4}$ Furthermore, in a letter commenting on Perino's then still unpublished report (1985) on a putative Sanders focus mortuary component at the Holdeman site, Brown (1991) opined that the Holdeman assemblage was McCurtain focus and remarked confidently, as I would have at the time, that "no one would now extend the Sanders focus outside of that site." Obviously, he was wrong.

In 1990, Dee Ann Story (Story et al. 1990:302, 174) called Krieger's treatment of the Sanders site material "preliminary, but insightful" and stated that the "Sanders site needs restudy and the Sanders focus redefinition." A year later she (1991:17) reaffirmed that "the oft-cited analysis of the Sanders site (Krieger 1946:172-218) is preliminary," adding that it "does not separate all components now identifiable in the artifact collections at TARL." Coming from the senior author (then Dee Ann Suhm) of the most recent formal description of the Sanders focus (Suhm, et al. 1954:176-182), where there is no hint that anything about it should be considered "preliminary," that is tantamount to a retraction of the concept. 
Volume $9(3 / 4)$

\section{Deconstructing the Sanders Phase}

So the Sanders focus is an ill founded, unconfirmed, and clearly unconfirmable, hypothesis that was justifiably rejected, beginning decades ago, by leading Caddo area archeologists. How then - on what basis - are Perttula and his colleagues now attempting to reincarnate it as the "Sanders phase," a taxon they claim is represented at "dozens of sites in southeastern Oklahoma and northeastern Texas" (Bruseth et al. 1995: 224-225)? The answer, as Bruseth's latest publication (1998) on the subject shows, is they are not talking about a phase. Rather, they have succumbed to "the confusion that inheres in practically all archaeological sequence formulations between culture and chronology" (Willey and Phillips 1962:28) and have assigned a phase name to a period ${ }^{5}$.

This is not apparent in the first published discussion of their "Sanders phase" concept (Bruseth et al. 1995), which contains only their unsupported assertion that at least 23 sites in the "middle Red and adjacent river valleys" harbor "probable Sanders phase components" (Bruseth et al. 1995:Table 1). However, that paper is based on a 1992 Southeastern Archeological Conference paper by Bruseth, a revised version of which has just appeared in print (1998:55-62), and there it is clear.

In his presentation of the culture history of the "Middle Red River" his "Early Ceramic" and "Formative Caddoan" periods are followed by two units labeled
"Sanders Phase Caddoan"and "McCurtain Phase Caddoan," an incongruity he acknowledges with the statement that: "At this point in the paper, the discussion shifts from examining Red River chronology in terms of periods to phases." His explanation for this is that "our knowledge of the archeological record [from the "Formative Caddoan period" on], while far from perfect, is sufficiently better to identify culturally related groups that occupied a restricted geographical area and existed over a fairly defined time." Then, on the grounds that "these are attributes that typically are used in the definition of a phase (cf. Willey and Phillips 1958)" he reaches the taxonomically (and lexically) grotesque conclusion that [emphasis mine]: ". . . the time from A.D. 1100-1300 refers to what is commonly known as the Sanders phase."

The trouble with this, as a more careful reading of Willey and Phillips (1962:11$57)$ on the subject of archeological systematics would have revealed, is that although occupation of "a restricted geographical area" and existence "over a fairly defined time" are, of course, "attributes" of phases once they have been formulated, they are not the attributes that are used to define them. A phase is "an archeological unit," not a temporal unit (those are periods), and not a spatial unit (those are localities, regions, and areas), that is defined archeologically, not temporally or geographically, on the basis of "possessing traits sufficiently characteristic to distinguish it from all other units 
similarly conceived, whether of the same or other cultures or civilizations, spatially limited to the order of magnitude of a locality or region and chronologically limited to a relatively brief interval of time" (Willey and Phillips 1962:22).

So when Perttula and his colleagues (Bruseth et al. 1995:226) try to counter my interpretation of the Sanders mortuary assemblage as the remains of an isolated outpost of Mississippian traders by arguing that there are "dozens of other" Sanders phase sites in northeast Texas and southeast Oklahoma all they are doing is asserting that there are dozens of other sites with occupations which appear to date to the period between A.D. 1100 and A.D. $1300^{6}$ when the Sanders site was in use. Of course there are. These are the sites that represent the Red River Caddo peoples with whom the Spiroans were trading.

\section{Reclassifying the So-called Sanders Focus, or Sanders Phase, Ceramics of Northeast Texas and Southeast Oklahoma}

The proof of this (although it is proof to which Perttula and Bruseth will be indifferent because they do not know, or do not care, that in standard archeological practice phases are defined culturally, not temporally and geographically) is the fact that not one of their so-called Sanders phase sites has yielded a Sanders phase assemblage. Bruseth, Wilson, and Perttula's (1995:Table 1) list of "sites with probable Sanders phase components" is not a list of sites for which more or less complete "Sanders phase" assemblages (by which I mean assemblages similar to the Sanders mortuary assemblage) have been documented. It is not even a list of sites that have produced complete, or nearly complete "Sanders phase" ceramic assemblages (by which I mean assemblages containing all five of the types - Canton Incised, Sanders Engraved, Maxey Noded Redware, Monkstown Fingernail Impressed and
Sanders Plain - that are fairly well represented in the Sanders mortuary assemblage) because no site listed is known to have such an assemblage. As my Table 1 shows, five lack one type, seven lack two types, five lack three types, two lack four types and five ${ }^{7}$, mirabile dictu, lack all five types ${ }^{8}$.

Furthermore, the types that are present are not represented in frequencies that are even remotely similar to their frequencies in the Sanders mortuary assemblage. Judging from that assemblage (as we must because it is the only evidence we have as to what a "Sanders phase" ceramic assemblage - if such existed - would look like), an assemblage of decorated Sanders phase pottery should consist of approximately $47 \%$ Sanders Engraved, $36 \%$ Maxey Noded Redware, 11\% Monkstown Fingernail Impressed, and 4\% Canton Incised (Krieger 1946: Table 6). 
Volume $9(3 / 4)$

\section{Sanders Engraved}

Yet, as Table $1^{10}$ shows, Sanders Engraved, which should be a major, if not the major, type in any "Sanders phase" assemblage, is unreported in 14 collections. In the nine collections for which it is reported, for a paltry total of 400 sherds and five pots, its distribution is inexplicably erratic in terms of the hypothesis that it represents "Sanders phase" components at these sites. Most of it, 305 sherds, is from the Taddlock site where the possibility that it represents a Sanders phase component is strongly, if not decisively, contraindicated by the absence of Maxey Noded Redware and Monkstown Fingernail Impressed, the other two decorated fineware types that should constitute a significant part of any "Sanders phase" assemblage, and by the absence of Sanders Plain.

The more probable explanation for so much so-called Sanders Engraved in the Taddlock sherd collections is that most of it is misclassified pottery of other types. Instead of classifying the pottery from Taddlock and the other Lake Fork Reservoir sites of importance here, Spoonbill and Hines, in the normal way, Bruseth and Perttula (1981:76-77), whose approach to ceramic classification is as idiosyncratic their approach to space-time systematics, sorted it into "element categories" which they defined as taxa "based only on design elements, without regard for temper, vessel form, and other attributes commonly included in typological classification." Then they lumped what they considered similar element categories into "type categories" to which they - unwisely and unjustifiably - assigned the names of established types ${ }^{11}$.

Thus the 305 so-called Sanders Engraved sherds from Taddlock (plus the four from Hines and the 12 from Spoonbill) can only be considered untyped engraved sherds that could belong to any of the types with rectilinear or curvilinear engraving known to occur in northeast Texas, i.e., Avery Engraved, Barkman Engraved, Bowie Engraved, Glassell Engraved, Hatchel Engraved, Hempstead Engraved, Hickory Engraved, Hodges Engraved, Holly Fine Engraved, Ripley Engraved, Spiro Engraved, Taylor Engraved and Womack Engraved. Considering the absence of Maxey Noded Redware $^{12}$, Monkstown Fingernail Impressed, and Sanders Plain at Taddlock, and the strikingly weak distribution of Sanders Engraved in all so-called Sanders phase assemblages (Tables 1 and 2), it is unlikely that more than a few of these sherds are from Sanders Engraved pots.

Also suspect are the 45 sherds and one pot from the Yarbrough site that Johnson (1961:226-229) called Sanders Engraved. They would only be that if one is as willing as he was to overlook the fact that "The execution of the design motifs and elements themselves is much more careless and crude on the Yarbrough site specimens than on the Sanders site examples." I am not. Judging from the one pot (Fig. 32 A.) and one sherd (Fig. 23 G) illustrated, much of this pottery is probably Womack Engraved (Duffield and Jelks 1961:35-37, Rohrbaugh 1982:487492), a type that would be at home with the shell tempered plain sherds in the allegedly (but obviously not) single 
component Sanders focus midden at this site (Johnson 1961:230).

\section{Maxey Noded Redware}

The figures for Maxey Noded Redware, which should be almost as well represented as Sanders Engraved in any "Sanders focus" or "Sanders phase" assemblage worthy of the name, are even more at odds with expectations. It is not reported for 17 sites and is grossly under represented in four of the seven collections for which it is reported. To judge from Perino's (1995) recently published report, the Holdeman site might be a noteworthy exception because the names Maxey Noded Redware and Maxey Noded Grayware ${ }^{13}$ are used to describe 13 bottles from 12 graves (Table 3). Nine (those from Burials 1, 3, 7, 11, 12/13, 20, 31, 52, and 18) are called Maxey Noded Redware, so they must be the specimens Perttula had in mind when (1997b:10) he claimed that "Canton Incised . . . Maxey Noded Redware ... and Sanders Plain ... are more common at the site than Schambach would have us believe, with nine ${ }^{14}$, nine, and $10{ }^{15}$ vessels apiece, ..."

There are, however, significant discrepancies (the result of editorial changes by Perttula, apparently) between the published identifications and descriptions of these nine specimens and those that appear in Perino's manuscript on the Holdeman site (1985) and in the Museum of the Red River's burial forms for the Holdeman site burials (Table 3). These create the impression that Maxey Noded Redware bottles are about three times as common as Perino's original manuscript and the museum records and collections indicate.
In Perino's manuscript (1985) the type name Maxey Noded Redware is used only three times, for bottles from Burials 1, 11, and 52, and (as I discovered when I examined the Holdeman site pottery and burial records at the Museum of the Red River in December 1997, and sketched and photographed many of the pots) in each case it is used correctly. These specimens conform ${ }^{16}$ in shape, surface finish, and decoration to the type description (Suhm and Jelks 1962:101) which, overly broad though it is ${ }^{17}$, specifies that the decorative treatments attested for this type are: "Applique, punctating; surface always red filmed," and leaves no doubt that the shape attested for the type specimens from Sanders is an " $A$ " shaped or pear-shaped bottle.

Furthermore, they represent two of the four varieties of this type I recognize in the holotype collection from Sanders and will now name. The bottles from Burials 1 and 52, which have vertical rows of applique nodes and vertical and horizontal rows of punctations, fit what I will call the Maxey variety, exemplified by specimens $\mathrm{B}$ and $\mathrm{C}$ in the Plate accompanying the type description (Suhm and Jelks 1962:Plate 51). The bottle from Burial 11, which has four horizontal rows of punctations at the base of the neck but no applique nodes and no vertical rows of punctations fits what I will call the Direct variety, exemplified by specimen $D$ in that Plate. (While I am at it, I will designate specimen A in Plate 51, a red slipped bottle with vertical rows of applique nodes but no punctations, the holotype specimen for a Unity variety and I will designate specimen E, the red slipped compound 


\section{Table 3. Maxey Noded Redware in the Holdeman Site Collection.}

\begin{tabular}{|c|c|c|c|}
\hline Burial & Perino 1995 & Perino 1985 & Museum of Red River Burial Form \\
\hline 1 & "Maxey Noded Redware bottle" (p. 26) & "Maxey Noded Redware bottle" (p. 19) & $\begin{array}{l}\text { "Red bottle . . tapering from wide } \\
\text { bottom to base of neck. Had three } \\
\text { groups of vertical appliqued nodes } \\
\text { extending from bottom to base of the } \\
\text { neck." }\end{array}$ \\
\hline 2 & $\begin{array}{l}\text { "The bottle was a plain red-slipped } \\
\text { Maxey Noded Redware shape but } \\
\text { lacked the nodes." (p. 29) }\end{array}$ & $\begin{array}{l}\text { "A plain red Maxey-shaped bottle" ( } p \text {. } \\
\text { 20) }\end{array}$ & "A plain red bottle" \\
\hline 3 & $\begin{array}{l}\text { "A Maxey Noded Redware bottle } \\
\text { rested near the left foot," (p. 29) }\end{array}$ & $\begin{array}{l}\text { "A Maxey Noded bottle was near the } \\
\text { left foot." (p. 21) }\end{array}$ & "Plain bottle was near left foot" \\
\hline 7 & $\begin{array}{l}\text { "Near the right elbow was a small } \\
\text { Maxey Noded Redware bottle," (p. 39) }\end{array}$ & $\begin{array}{l}\text { "a small Maxey Noded bottle was near } \\
\text { the right elbow" (p. 23) }\end{array}$ & $\begin{array}{l}\text { "Small bottle with noded panel dividers } \\
\text { was near right elbow." }\end{array}$ \\
\hline 11 & $\begin{array}{l}\text { "a Maxey Noded Redware bottle was } \\
\text { by the left knee." (p. } 41)\end{array}$ & $\begin{array}{l}\text { "a Maxey Noded Redware bottle } \\
\text { found near the left knee." (p. 24) }\end{array}$ & $\begin{array}{l}\text { "Red bottle with four horizontal rows of } \\
\text { small punctates at the base of the neck } \\
\text { found near the left knee." }\end{array}$ \\
\hline $12 / 13$ & $\begin{array}{l}\text { "a plain buff-colored Maxey Noded } \\
\text { "Redware" bottle below the right arm." } \\
\text { (p. 41) }\end{array}$ & $\begin{array}{l}\text { "a plain buff-colored Maxey Noded } \\
\text { bottle below the right arm." (p. 25) }\end{array}$ & $\begin{array}{l}\text { "A plain buff bottle was under Burial } \\
12 \text { 's right arm" }\end{array}$ \\
\hline 20 & $\begin{array}{l}\text { "... near the right lower leg, a Maxey } \\
\text { Noded Redware bottle and a Canton } \\
\text { Incised jar" (p.49). }\end{array}$ & $\begin{array}{l}\text { "a Maxey Redware bottle of aberrant } \\
\text { form and a Canton Incised jar. Both } \\
\text { were found near the lower right leg" (p. } \\
\text { 33). }\end{array}$ & $\begin{array}{l}\text { "Red bottle similar to Maxey Redware } \\
\text { having six horizontal rows of small } \\
\text { punctates at base of the neck found near } \\
\text { right foot. Canton Incised jar found next } \\
\text { to bottle." }\end{array}$ \\
\hline 31 & $\begin{array}{l}\text { "a Maxey Noded Redware bottle" (p. } \\
45 \text { ) }\end{array}$ & "a Maxey Grayware bottle" (p. 28) & "Maxey Noded Grayware bottle" \\
\hline 37 & $\begin{array}{l}\text { "the bottle is Maxey Noded Grayware" } \\
\text { (p.45) }\end{array}$ & "a Maxey Grayware bottle" (p.29) & "grayware Maxey bottle" \\
\hline 39 & $\begin{array}{l}\text { "a Maxey Noded grayware bottle" (p. } \\
\text { 46) }\end{array}$ & $\begin{array}{l}\text { "a Maxey Grayware bottle having } \\
\text { squares and angles in close order." (p. } \\
\text { 29) }\end{array}$ & $\begin{array}{l}\text { "Grayware bottle similar to Maxey type } \\
\text { but having lines and angles, small } \\
\text { triangles and small squares and } \\
\text { rectangles. Red pigment is in lines." }\end{array}$ \\
\hline 52 & $\begin{array}{l}\text { "The bottle was of the Maxey Noded } \\
\text { Redware type." (p. } 47)\end{array}$ & $\begin{array}{l}\text { "A Maxey Noded Redware bottle" (p. } \\
\text { 31) }\end{array}$ & "A Maxey Noded Redware bottle." \\
\hline 18 & $\begin{array}{l}\text { "In addition to the } 11 \text { ceramic vessels } \\
\text { (seven bowls, two bottles and two jars" } \\
\text { "The ceramic bottle by the right } \\
\text { shoulder has the shape of a Maxey } \\
\text { Noded Redware bottle, but it was } \\
\text { decorated with fine engraved lines on } \\
\text { the body. A second bottle with burial } \\
\text { 18 has six rows of tool punctates on the } \\
\text { upper body of the vessel. This appears } \\
\text { to be a Maxey Noded Redware botte." } \\
\text { (p. 49) }\end{array}$ & $\begin{array}{l}\text { "Ten vessels and other artifacts were } \\
\text { associated." They consisted of ... a } \\
\text { large red carinated-rim bowl... a small } \\
\text { straight- sided bowl ... another like it } \\
\ldots \text { an engraved bottle having the } \\
\text { Maxey bottle form but an aberrant } \\
\text { decoration } \\
\ldots \text { near the right shoulder ... two } \\
\text { identical Canton Incised... jars ... a } \\
\text { large gray carinated-rim bowl... a } \\
\text { plain oval bowl... a bowl made from } \\
\text { the bottom of a large jar... a large } \\
\text { gray carinated-rim bow." (p. } 32 \text { ) }\end{array}$ & $\begin{array}{l}\text { "Large red carinated bowl ... } \\
\text { Small vertical sided bowl... } \\
\text { Nearly identical bowl... } \\
\text { Maxey-shaped bottle with ... engraved } \\
\text { and cross-hatched decorations on the } \\
\text { body. } \\
\text { Two identical jars... having broad } \\
\text { Canton-like decorations on rim ... } \\
\text { Large gray carinated bowl. . } \\
\text { Plain oval bowl... } \\
\text { Large bowl made from bottom of jar.. } \\
\text { Large gray carinated bowl.... }\end{array}$ \\
\hline
\end{tabular}


bottle decorated with horizontal rows of punctations and horizontal fillets, the holotype for a Jackson variety).

The var. Maxey bottles from Burials 1 and 52 and the var. Direct bottle from Burial 11 are the specimens I refer to in Table 6 (see below), which presents my estimates of how much pottery of the types common in the Sanders mortuary assemblage has been found at the 23 northeast Texas and southeast Oklahoma sites that Bruseth, Wilson, and Perttula (1995) have identified as sites with probable Sanders phase components.

The other seven specimens identified as Maxey Noded Redware in Perino's published report (those from Burials 2, 3, 7, $12 / 13,20,31$, and 18) are not so identified in his manuscript. There (Table 3 ) he refers to them less formally using several variations of the type name Maxey Noded Redware: "Maxey-shaped," "Maxey Noded " and "Maxey Redware." The reason for this (as I know from my 1985 correspondence with him on the subject of the classification of the Holdeman site pottery) is that he was new to the practice of Caddo area archeology in 1985 and, baffled and frustrated by the vagaries and inconsistencies of Caddo area ceramic typology as it is presented in the Handbook of Texas Archeology (Suhm and Jelks 1962), he used the terms "Maxeyshaped," "Maxey Noded" and "Maxey" as descriptors for an ad hoc, catchall category of bottles that seemed to him to resemble bottles of the type Maxey Noded Redware in some ways, but not enough to be classified as such. So Perttula's editorial decision to substitute the type name for these descriptors in the published report was the wrong one. Neither the type name nor Perino's descriptors should have been used for these specimens.

The bottle from Burial 2 (Table 3), described in print as "a plain red-slipped Maxey Noded Redware shape [that] lacked the nodes" (Perino 1995:29), described in Perino's manuscript as a "plain red Maxey-shaped bottle," and described in the Museum burial form as "a plain red bottle," should have been described as "a plain red bottle." It lacks both nodes and punctations and its shape alone ${ }^{18}$, absent a drawing or a photograph, is of no descriptive or classificatory significance because the type description ${ }^{19}$ (unfortunately and erroneously) includes bottles of three shapes that are not attested in the holotype collection - the bottles in the Sanders mortuary assemblage.

The bottle from Burial 3 (Table 3), called a "Maxey Noded Redware" bottle in the published version of Perino's report (1995:29) and described as a "Maxey Noded bottle" in his manuscript (1985: 21 ), should have been called a "plain bottle," as it is described on the museum burial form. When I examined this specimen I discovered that it is a plain shell-tempered bottle.

The bottle from Burial 7 (Table 3), described in print as a "small Maxey Noded Redware" bottle (Perino 1995:39), and as "a small Maxey Noded bottle" in Perino's manuscript (Perino 1985:24), should have been called a "small bottle with noded panel dividers," which is how it is described on the museum burial form. 
Volume 9(3/4)

This specimen (I have examined and photographed it) is not Maxey Noded Redware because it is not red slipped, but gray slipped; because it is globular, not "A" shaped; because it lacks the punctations exhibited by most specimens of this type; and because the nodes are unlike the nodes of Maxey Noded Redware in shape and placement. They are large, oval, appliques wide-spaced in four rows of three each that divide the body of the bottle into four panels.

The "plain, buff-colored Maxey Noded 'Redware' bottle listed for Burial 12/13 in the published report (Perino 1995:41) is more accurately described on the museum burial form as "a plain buff bottle."

The Burial 20 bottle, described in print (Perino 1995:49) as a "Maxey Noded Redware bottle," is more accurately described on the museum burial form (Table 3) as a "Red bottle similar to Maxey Redware [in] having six horizontal rows of punctates at base of the neck." As Perino indicates in his manuscript description (Perino 1985: 33 ), and as is clear from the published photo (Perino 1995:Figure 6b), this is a bottle "of aberrant form" for this type. The form is globular rather than the distinctive "A" shape which is characteristic of all the Maxey Noded Redware bottles in the type collection from the Sanders site (Krieger 1946:Plate 29, a-c, Suhm and Jelks 1962:Plate 51, A-E). This and the absence of nodes removes it from the realm of Maxey Noded Redware as the type is exemplified in the Sanders mortuary assemblage. It is simply a red, punctated, bottle - untypable at present.
Judging from the illustration (Perino 1995:Figure 6C), the bottle from Burial 31 has the shape, nodes and punctations, and decorative style diagnostic of Maxey Noded Redware. However, its classification as such is compromised by the fact that in Perino's manuscript (1985:28) the only "Maxey" bottle (indeed, the only bottle; Table 4) reported for Burial 31 is called a "Maxey Grayware" bottle, as it is on the Museum burial form (Table 3). Unfortunately, I could not find this specimen in the Holdeman site collection, so the simple question of what color it is cannot be answered. If, as I suspect, it is gray then it cannot be Maxey Noded Redware, which Krieger $(1946: 338,190)$ defined as "always bearing a hard-baked red film on exterior only." However, it might be a locally made unslipped copy of this type which, according to my Sanders entrepot hypothesis, would have been a rare and valuable imported ${ }^{20}$ Mississippian pottery type for the local Caddo.

The "Maxey Noded Redware" bottle reportedly found (I could not find it in the collection) with Burial 18 (Perino 1995:49, Figure 6b) appears to be a double entry. It is not mentioned (Table 3 ) in Perino's 1985 description of the contents of Burial 18; nor is it inventoried on the museum burial form; nor is it shown in the drawing of Burial 18. According to these sources there were 10 pots in this grave, not the 11 listed and described in the published report. However, the published illustration (Perino 1995:Figure 6b) of this missing, extra, specimen is that of a bottle exactly like the red, punctated bottle found in Burial 20 (Table 3), but not illustrated. 
Table 4. Pottery types associated with Maxey Noded Redware and so-called Maxey Noded Redware in the Holdeman site grave lots.

\begin{tabular}{|c|c|c|c|c|c|c|c|c|c|c|c|c|}
\hline Burial & 1 & 2 & 3 & 7 & 11 & $12 / 13$ & 20 & 31 & 37 & 39 & 52 & 18 \\
\hline $\begin{array}{l}\text { Maxey Noded Redware var. } \\
\text { Maxey }\end{array}$ & 1 & & & & & & & & & & 1 & \\
\hline $\begin{array}{l}\text { Maxey Noded Redware var. } \\
\text { Direct }\end{array}$ & & & & & 1 & & & & & & & \\
\hline "Maxey Like" & & 1 & 1 & 1 & & 1 & 1 & & & & & 1 \\
\hline "Maxey Grayware" & & & & & & & & 1 & 1 & 1 & & \\
\hline Canton Incised & & & & & 1 & & 1 & & & & & \\
\hline $\begin{array}{l}\text { "Canton Incised" jar with strap } \\
\text { handles, applique designs on } \\
\text { body }\end{array}$ & & & & & & & & & & & & 2 \\
\hline $\begin{array}{l}\text { "Sanders Engraved" bowl with } \\
\text { East Incised rim lugs }\end{array}$ & & & & & 1 & & & & & & & \\
\hline "Sanders Engraved" Jar & & & & & & & & & 1 & & & \\
\hline Sanders Incised" jar & & & 1 & & & & & & & & & \\
\hline "Spiro Engraved" bowl & & & & & & & & & 1 & & & \\
\hline Spiro Engraved bottle & & 1 & & & & & & & & & & \\
\hline "East Incised" bird effigy bowl & & 1 & & & & & & & & & 1 & \\
\hline Black "Late East Incised" bowl & & 1 & & 1 & & & & & & & & \\
\hline East Incised bowl (red slipped) & & 1 & & & & & & & & & & \\
\hline Maydelle Incised & & 1 & & & & & & 1 & & & & \\
\hline Red Bowie Engraved bowl & & 1 & & & & & & & & & & \\
\hline Emory Punctated & & & 3 & & & & & & & & & \\
\hline Nash Neck Banded & & & 1 & & & & & & & 1 & & \\
\hline $\begin{array}{l}\text { Strap-handled jar with applique } \\
\text { decoration }\end{array}$ & & & & & & & & & & & 1 & \\
\hline Avery Engraved & & & & 1 & & & & & & & & \\
\hline Moore Noded & & & & 1 & & & & & & & & \\
\hline Taylor Engraved & & & & 1 & & & & & & & & \\
\hline McKinney Plain & & & 2 & 2 & & 1 & & & & & & \\
\hline $\begin{array}{l}\text { Plain jar / bowl made from base of } \\
\text { jar }\end{array}$ & & 1 & & 1 & & & & & & 1 & 1 & 1 \\
\hline Red bowl & & 1 & & & & & & 1 & & 1 & & 1 \\
\hline Plain bowl with rim lugs/spouts & 1 & & 1 & & & & & & & 1 & & \\
\hline Pain bowls & 4 & 5 & & 1 & 1 & & & 1 & & 2 & & 5 \\
\hline Bow with scalloped rims & 2 & & & & & & & & 2 & & 3 & \\
\hline
\end{tabular}


On the museum burial form that specimen (as noted, I could not find it in the Holdeman collection either) is described as a "Red bottle similar to Maxey Noded Redware having six horizontal rows of small punctations at the base of the neck." The description in Perino's manuscript (1985:33) adds the crucial detail that it is a "Maxey Redware bottle of aberrant form." That, as I have pointed out, is certainly true of the bottle illustrated as Figure $6 b$.

The grave lot data presented in Table 4 (which are from the identifications and descriptions in Perino's 1985 manuscript rather than his over-edited published report) reinforce my attribute-based argument that nine of the twelve "Maxey Noded Redware" and "Maxey-like" bottles reported in print for the Holdeman site do not belong to that type. Contrary to expectations based on the Sanders mortuary assemblage, these nine do not appear in grave lots consisting mainly of the types Sanders Engraved, Monkstown Fingernail Impressed, Canton Incised, and Sanders Plain - the types "traditionally identified with the Sanders phase of northeastern Texas," as Bruseth (1998:51) has acknowledged. There is no Sanders Engraved pottery in these grave lots. The so-called "Sanders Engraved" jar from Burial 37 could hardly be that because Sanders Engraved is primarily a bowl type and jars are unattested (Suhm and Jelks 1962:137). There is no Monkstown Fingernail Impressed. The single "Canton Incised" specimen listed for Burial 20 is a globular pot, a form not attested for Canton Incised, (Suhm and Jelks 1962:23) which I have reclassified below as the Kaufman variety of Avoyelles Punctated. And no one has identified bowls of the type Sanders Plain among the many plain bowls from these graves.

The disparate group of decorated types with which these specimens do occur (Spiro Engraved, East Incised, Maydelle Incised, Bowie Engraved, Emory Punctated, Nash Neck Banded, Avery Engraved, Moore Noded, Taylor Engraved, and McKinney Plain, the last a decorated type despite the name), their equally disparate probable time spans (Perttula 1995a: Table 9, Bruseth 1998:51 and Table 3-1) and the fact that there is considerable inconsistency between grave lots, are all indications that they are misclassified specimens of various types pertaining to several Red River Valley phases, some yet to be defined, ${ }^{21}$ that may both pre- and post-date the occupation of the Sanders entrepot and the use life of the type Maxey Noded Redware. Thus, Burial 2 with its Spiro Engraved and East Incised pottery probably predates by more than a century Burials 3, 7, and 37 which Perttula (1995a:Table 3) considers early McCurtain phase.

On the other hand, the three real Maxey Noded Redware bottles cooccur with pots that are mostly similar, if not typologically identical, to specimens in the Sanders mortuary assemblage. Ten of the 32 plain bowls (including five of the seven bowls with scalloped rims) listed in Table 4 are from the three graves that produced these bottles. Some of these, particularly some of the six from Burial 1, may prove to be Sanders Plain. 
The so-called "Sanders Engraved" bowl accompanying the Maxey Noded Redware var. Direct bottle from Burial 11 is not that but (as would be obvious, were it illustrated) an apparently unique and therefore presently untypable, tan slipped, shallow bowl with two well formed rim tabs similar to those on East Incised bowls and a rectilinear, not particularly Sanderslike, engraved design on the rim. But the other decorated specimen in this grave lot, the (also unillustrated) "Canton Incised" bowl, is an excellent example of the only type and variety of the three types heretofore mistakenly subsumed in the old and (as I show below) egregiously overly inclusive type "Canton Incised" that is attested in the Sanders mortuary assemblage. This is a variety I have reclassified (see below and Figure 3) as Avoyelles Punctated var. Canton. The grave lot in which one of the two Avoyelles Punctated var. Canton jars in the Sanders mortuary assemblage occurs, the B-9 lot, also includes one of the two Maxey Noded Redware var. Direct bottles from Sanders. Therefore Burial 11 at Holdeman was probably put in place while the Sanders entrepot was in operation.

However, for reasons given below in my discussion of the role the bogus type "Canton Incised" has played in the creation and perpetuation of the equally bogus Sanders focus, I consider it a Caddo, rather than a Spiroan, grave that contained two locally made Caddo pots, the so-called Sanders Engraved bowl and the Avoyelles Punctated var. Canton jar, and one Spiroan import from the Arkansas Valley, the Maxey Noded Redware var. Direct bottle. In other words, I hypo- thesize that the person interred in Burial 11 at Holdeman was not part of the Spiroan population ${ }^{22}$ in residence at the Sanders site at the time. He or she was part of the local Caddo population, a population that manufactured Avoyelles Punctated var. Canton as a utility ware and occasionally obtained Maxey Noded Redware bottles from the Spiroan traders at Sanders (who occasionally obtained Avoyelles Punctated var. Canton from them).

The same is probably true of the person and the Maxey Noded Redware var. Maxey bottle interred in Burial 1; i.e., the person was Caddo, but the pot was Spiroan. However, we cannot be sure about this, or even that it is the best hypothesis, until we learn as much as can be learned about where the seven plain bowls in that grave lot originated, something that will require that they, and all the plain bowls from Sanders as well, be studied, described, and classified.

Then we may also be able to tell whether the three plain bowls with scalloped rims associated with the Maxey Noded Redware var. Maxey bottle from Burial 52 were made by the local Caddo or were obtained from the Spiroans at Sanders, who either imported them from the Arkansas Valley or made them themselves locally in Arkansas Valley Mississippian styles. The bowl from this grave, a specimen Perino (1995:47) classifies as an "East Incised bowl with a duck effigy on the rim" is also probably a Spiroan import. Following Phillips, Ford and Griffin (1951:147-148), I classify it (Perino 1995: Figure 23, F) and a nearly identical speci- 

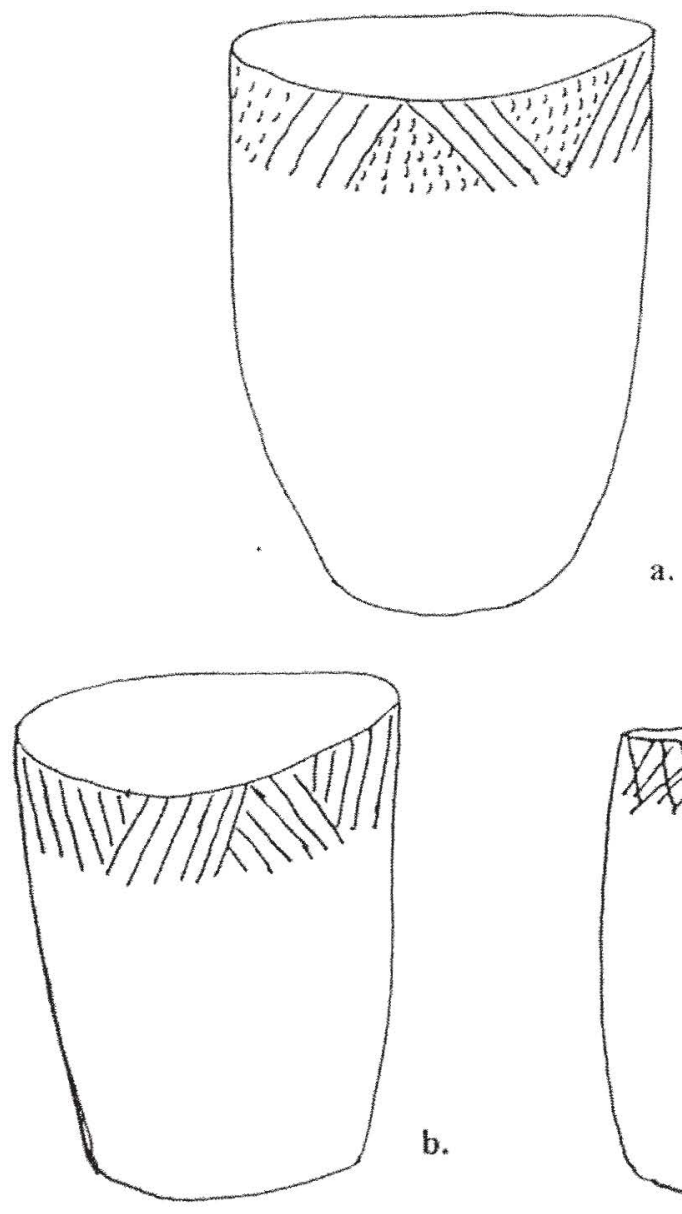

b.

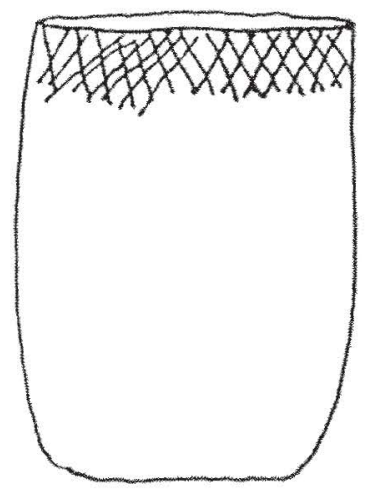

Figure 3. A reclassification of Canton Incised pottery: a) Avoyelles Punctated var. Canton (after Suhm and Jelks 1962:Plate 12,D; "Canton Incised" pot from "Sanders Focus" burial at the Sanders site); b) Mazique Incised (after Suhm and Jelks 1962:Plate $12, \mathrm{~F}$ and G; sherds of "Canton Incised" from the middens at the Sanders site); c) Harrison Bayou Incised (after Johnson 1962:Fig. 22, B; "Canton Incised" site from the Yarbrough site).

men from Burial 2 as a variety of the type Mound Place Incised which, I have suggested (1993a:205), was imported via the Spiroan trade network from the Mississippi Valley.

I had thought that because these bowls are not attested in the Sanders mortuary assemblage (although there is an excellent fragmentary specimen in the T.A.R.L. collection of unprovenienced pots collected from the surface at Sanders ${ }^{23}$ ), all of them probably pertained to activities of Spiroan traders in the Red River Valley 
after the period represented by that assemblage. However, the association of this bowl with a Maxey Noded Redware var. Maxey bottle suggests that (unless the bottle, which was patched aboriginally, as noted above, was an heirloom of considerable age by the time it was interred) this variety of these incised effigy bowls, which I will call Mound Place Incised var. Albion, was being imported while Maxey Noded Redware bottles were being interred at Sanders.

The apparent relationships of the only other decorated pot from this grave seem to confirm this. Perino (1995:47) describes this specimen as a "tan-colored vessel with continuous V-shaped appliqued strips across the body and two strap handles with twin projections above the rim; each handle had three longitudinal clay appliqued strips." This sounds (unfortunately it is not illustrated) very much like a jar (V-305) that accompanied a Maxey Noded Redware var. Maxey bottle (V-303) in Burial B-5 at Sanders. It is described in the Texas Archeological Research Laboratory's Ceramic Inventory for the Sanders site (p. 8) as "Bowlminiature-complete-good condition. Jarshaped with two handles, flared lip, constricted neck. Plain except for 1 continuous applique line running from handle to handle in a "W" design. Base is flat." In form, decorative technique, and design these specimens fit the type Woodward Applique, defined by Brown (1996:393) on the basis of 12 whole pots and sherds "of an additional vessel" from Spiro. This is defined as a shell tempered type but, for two reasons, that need not be an obstacle to classifying these specimens as Woodward Applique. The temper of the Holdeman and Sanders specimens (which, to judge from the range of tempers in evidence in both collections, could be either shell or grog) is unreported, and an unrecognized grog tempered variety of this type seems to be represented at Spiro where it is classified as "Undesignated Applique" (Brown 1996:369).

\section{Monkstown Fingernail Impressed}

Monkstown Fingernail Impressed, which should be a consistently represented minority type in all "Sanders phase" assemblages, is reportedly represented by one sherd from the Mahaffey site, one from the Yarbrough site, and two (unillustrated) pots from the Spoonbill site (Table 1). Significantly, this type is not represented among the 106 pots from the 21 Holdeman site graves Perttula (1995a:Table 9) classifies as "Sanders Phase." I doubt that this is the result of sampling error and I am reminded of Krieger's (1946:191) suggestion that the five pots of this type in the Sanders mortuary assemblage "may represent a trade ware."

\section{"Canton Incised"}

Predictably, Canton Incised is not represented according to expectations based on the Sanders mortuary assemblage either, but the deviation is in the opposite direction and extraordinarily pronounced. This type amounts to only $5 \%$ (2) of the 38 decorated pots of "Sanders focus types" from the graves at Sanders (Krieger 1946: Table 6), only $3.2 \%$ of the 62 pots of all types from the graves (Krieger $1946: 185$ ), and only $2.7 \%$ of the 74 pots from the entire site (Krieger 1946:Table 
6). Yet, as Tables 1 and 2 show, it is the most commonly and consistently identified decorated "Sanders focus" or "Sanders phase" pottery type in northeast Texas and southeast Oklahoma. Seventysix percent, or 1427, of the 1868 decorated sherds reported from the 23 sites besides Sanders on Bruseth, Wilson, and Perttula's list (1995:Table 1) are identified as Canton Incised, while only $21 \%$ are identified as Sanders Engraved, 2\% as Maxey Noded Redware, and about $0.1 \%$ as Monkstown Fingernail Impressed. The figures presented in Table 2 are comparable: $72 \%$, or 276 of the 383 decorated "Sanders phase" sherds represented at the 17 sites and parts of sites on Perttula's supplementary list are reportedly Canton Incised, while only 94 (24.5\%) are reportedly Sanders Engraved, and $13(3.4 \%)$ are reportedly Maxey Noded Redware.

No wonder devotees of the Sanders focus/Sanders phase concept think that "The most common decorated Sanders Focus ceramic type is Canton Incised" (Bruseth and Perttula 1981:89). To them, Canton Incised is both the prime marker type for so-called Sanders focus or Sanders phase assemblages and the mainstay of the Sanders focus/Sanders phase concept. As more than one Caddo area archeologist has asked me: If there is no Sanders focus and no Sanders phase, what is the explanation for all the Canton Incised pottery at sites in northeast Texas and southeast Oklahoma?

My explanation is that Canton Incised, a type established by Krieger when Caddo ceramic taxonomy was in its infancy and he was a novice, but dangerously opinionated, taxonomist, is not a valid type, much less a securely attested "Sanders focus" or "Sanders phase" type. According to modern standards ${ }^{24}$ for ceramic taxonomy - the very standards repeatedly advocated by Perttula (1995a:68, 1995:183) for east Texas pottery - it is, as I demonstrate below, a conglomeration of three types: Avoyelles Punctated, Mazique Incised, and Harrison Bayou Incised. The latter two, which account for at least $64 \%$ of the 1559 sherds of Canton Incised pottery identified in collections from Bruseth, Wilson, and Perttula's 23 sites, and from the 1941 excavations in the middens at Sanders (Table 5), have no documented relationship with the Sanders mortuary assemblage, while Avoyelles Punctated is represented therein by just two pots, pots that the Spiroans at Sanders probably obtained in trade from the local Caddo ${ }^{25}$.

I base the latter conclusion on the weak representation of this type in the Sanders mortuary assemblage and on my perception that it differs stylistically from all other types in that assemblage but is obviously, since until now archeologists have been willing to accept it and them as a single type - similar to the local types Mazique Incised and Harrison Bayou Incised. It is reinforced by the fact that these pots would not be the only two traded pots in the Sanders mortuary assemblage. As Krieger recognized (1946: 191, 217), and as certain outstanding specimens such as the negative painted bottle from burial 15 (Krieger 1946:191 and Plate 28c) and the Bell Plain olla (Griffin 1952:Figure 127i, Krieger 1946: 197 and Fig. 17) from burial B-11 attest, it 
contains an extraordinary amount of pottery that is obviously or probably traded. The Spiroans interred at Sanders were traders and transporters of pottery as well as other goods and it appears that they obtained some of that pottery locally.

So in my view none of the pottery now classified as Canton Incised has a generic relationship with the pottery of the Sanders mortuary assemblage. It is local Caddo-made pottery that was in use around the time the Sanders entrepot was in use $^{26}$. It should be reclassified as follows.

\section{Avoyelles Punctated var. Canton}

The two Canton Incised pots from the Sanders mortuary assemblage are practically identical plain-bodied cylindrical jars with rim decorations consisting of triangular panels of fingernail punctations separated by zigzagging, diagonally incised, parallel lines, as shown in Figure 3, a (see also Krieger 1946:Plate 28, f and g, Suhm and Jelks 1962:Plate 12, d). Considering temper, surface finish, vessel shape, design placement, decorative techniques and decorative motif, I place them in what I will call the Canton variety of the Lower Mississippi Valley and Red River Valley type Avoyelles Punctated (Phillips 1970:41-43, Webb 1983:202-203 and Figure 4k).

Judging from the descriptions and illustrations of the 1559 sherds classified as Canton Incised in the literature on the 24 sites and parts of sites on Bruseth, Wilson, and Perttula's list of sites with probable Sanders phase components, I estimate (Table 5) that only $9 \%$ to $12 \%$ of them (or between 147 and 193 sherds) came from pots like the two in the Sanders mortuary assemblage, i.e., pots I would classify as Avoyelles Punctated var. Canton.

\section{Mazique Incised var. Manchac}

As I learned when I examined the Sanders site collection at the Texas Archeological Research Laboratory in 1995, only 15 of the 132 sherds from the middens that Krieger (1946:Tables 5 and 6) classified as Canton Incised can be classified as Avoyelles Punctated var. Canton. Eighty-eight of the remaining 117,45 rims and 43 lipless rim or body sherds, have un-Avoyelles-like diagonally incised straight line designs without punctations, as shown in Figure 3, b (Suhm and Jelks 1962:Plate 12, $\mathrm{f}$ and g). They fit the Red River Valley type Dunkin Incised as described by Webb (1963:160161 and Fig.7) from sites in northwest Louisiana, a type that should be merged with the Lower Mississippi Valley and Red River Valley type Mazique Incised (Phillips 1970:129-130, Webb 1983:193). Most of these sherds fit the Manchac variety. New local varieties should be established to subsume those that do not.

\section{Harrison Bayou Incised}

Another 22 of the 132 "Canton Incised" sherds from the middens at Sanders are crosshatched-incised rims from plainbodied, cylindrical jars, as shown in Figure 3, c (Suhm and Jelks 1962:Plate 12 c). They belong to the Lower Mississippi Valley and Red River Valley type Harrison Bayou Incised (Phillips 1970:6768). James A. Ford (1936:96-97 and Fig. 
Table 5. Probable incidences of the types Avoyelles Punctated, Harrison Bayou Incised and Mazique Incised in collections containing pottery now classified as Canton Incised.

\begin{tabular}{|c|c|c|c|c|c|}
\hline $\begin{array}{l}\text { So-called Sanders } \\
\text { phase sites }\end{array}$ & $\begin{array}{l}\text { So-called } \\
\text { Canton Incised }\end{array}$ & $\begin{array}{l}\text { Punctated } \\
\text { incised } \\
\text { (Avoyelles) }\end{array}$ & $\begin{array}{l}\text { Crosshatched } \\
\text { incised } \\
\text { (Harrison } \\
\text { Bayou) } \\
\end{array}$ & $\begin{array}{l}\text { Diagonal incised } \\
\text { (Mazlque Incised) }\end{array}$ & References \\
\hline A. C. Mackin & 1 & 0 & 0 & $1(100 \%)$ & Mallouf $1976: 282$ \\
\hline Baldwin & 2 & 0 & $1(50 \%)$ & $1(50 \%)$ & Rohrbaugh 1968:108 \\
\hline Beaver & 37 & present & present & present & Wyckoff 1968:88-89 \\
\hline Bell & 0 & 0 & 0 & 0 & Wyckoff 1968: Table IV \\
\hline Clement & 0 & 0 & 0 & 0 & $\begin{array}{l}\text { Bell and Baerreis } \\
1951: 53-55\end{array}$ \\
\hline Cook & 1 & 0 & 0 & 0 & Rohrbaugh 1973:186 \\
\hline E. Johnson & 29 & $\begin{array}{l}\text { "a few } \\
\text { sherds" }\end{array}$ & $\begin{array}{l}3 \text { of the sherds } \\
\text { illustrated }\end{array}$ & $\begin{array}{l}\text { "predominantly } \\
\text { incising" }\end{array}$ & $\begin{array}{l}\text { Wyckoff } 1967: 109, \text { Plate } \\
\text { XXV, } \\
7-13\end{array}$ \\
\hline Fasken & 0 & 0 & 0 & 0 & Prikryl 1991, 1992 \\
\hline Gregory & 10 & present & present & 0 & Wyckoff 1968:136-138 \\
\hline Harling & 0 & 0 & 0 & 0 & Davis 1962 \\
\hline Hines & 9 & 0 & $5(56 \%)$ & $4(44 \%)$ & $\begin{array}{l}\text { Bruseth and Perttula } \\
\text { 1981: Table 5-8 }\end{array}$ \\
\hline Holdeman & 8 pots & 4 pots & 1 pot & 3 pots & $\begin{array}{l}\text { Perino n.d; Perino } 1995 \text { : } \\
\text { Fig. } 6 \mathrm{~b} \text {, } \\
\text { Fig. } 23 \text { a, b; my } \\
\text { examination, 12-18-97 }\end{array}$ \\
\hline Kaufman, E. Md. & 4 & 4 & 0 & 0 & Skinner et al. 1969:47 \\
\hline Mahaffey & 41,1 pot & $\begin{array}{l}\text { not illust. or } \\
\text { described }\end{array}$ & $\begin{array}{l}\text { not illustrated or } \\
\text { described }\end{array}$ & $\begin{array}{l}4 \text { sherds } \\
\text { illustrated }\end{array}$ & $\begin{array}{l}\text { Perino and Bennett } \\
\text { 1978:74, } \\
\text { Fig. } 23 \mathrm{e}-\mathrm{h}\end{array}$ \\
\hline Nelson & 83 & $21(25 \%)$ & $11(13 \%)$ & $51(62 \%)$ & Rohrbaugh 1973:188 \\
\hline Pat Boyd & 284 & $10(9.4 \%)$ & present & "most popular" & Rohrbaugh 1973:86-87 \\
\hline Payne & 12 & 0 & 0 & $12(100 \%)$ & Rohrbaugh 1973:10 \\
\hline Pine Croek & 0 & 0 & 0 & 0 & Gettys 1975 \\
\hline Roitsch & 0 & 0 & 0 & 0 & Mattin 1991. 1992 \\
\hline Sanders middens & 132 & $15(11 \%)$ & $22(17 \%)$ & $88(66 \%)$ & $\begin{array}{l}\text { My examination, } 11-28 \text { - } \\
1995\end{array}$ \\
\hline Spoonbill & 30 & $2(7 \%)$ & $24(80 \%)$ & $4(13 \%)$ & $\begin{array}{l}\text { Bruseth and Perttula } \\
\text { 1981: Table } 5-8 \\
\end{array}$ \\
\hline
\end{tabular}


Table 5 (continued). Probable incidences of the types Avoyelles Punctated, Harrison Bayou Incised and Mazique Incised in collections containing pottery now classified as Canton Incised.

\begin{tabular}{|l|l|l|l|l|l|}
\hline $\begin{array}{l}\text { So-called } \\
\text { Sanders phase sites }\end{array}$ & $\begin{array}{l}\text { So-called } \\
\text { Canton Incised }\end{array}$ & $\begin{array}{l}\text { Punctated } \\
\text { incised } \\
\text { Avoyelles) }\end{array}$ & $\begin{array}{l}\text { Crosshatched } \\
\text { incised } \\
\text { (Harrison } \\
\text { Bayou) }\end{array}$ & $\begin{array}{l}\text { Diagonal incised } \\
\text { (Mazique Incised) }\end{array}$ & References \\
\hline Taddlock & 758 & $95(12 \%)$ & $445(60 \%)$ & $218(28 \%)$ & $\begin{array}{l}\text { Bruseth and Pertiula } \\
1981: \text { Table } 5-8\end{array}$ \\
\hline T. Moody & 0 & 0 & 0 & 0 & Perttula et. al. 1988 \\
\hline Woods Md & 0 & 0 & 0 & 0 & Wyckoff 1967:49-59 \\
\hline Yarbrough B & 126,1 pot & $15(12 \%)$ & $60(48 \%)$ & $51(40 \%)$ & $\begin{array}{l}\text { Johnson 1961:226-227, } \\
\text { Fig.23, a-f }\end{array}$ \\
\hline Totals & 1559,10 pots & 162,4 pots & 571,1 pot & 434,3 pots & \\
\hline
\end{tabular}

$18 \mathrm{j}$ ) had already isolated this type at the Harrison Bayou site, not far to the southeast of the Sanders site, in Harrison County, Texas, when Krieger - whose refusal to use Ford's types is legendary in Caddo area archeology - was writing the Sanders report. It was formally described in print (Quimby 1951:115-117 and Fig.16) three years before Suhm, Krieger, and Jelk's (1954:254) description of Canton Incised, which mistakenly subsumes it, was published.

At least three varieties are evident in collections from northeast Texas sites. The cylindrical jars with crosshatched rims and plain bodies just described (Figure 3c) fit Phillips's (1970:87-88) Harrison Bayou variety. The flared-rim jars with crosshatched-incised rims and plain bodies that are now assigned to the obvious catchall type Maydelle Incised
(Suhm and Jelks 1962:103 and Plate 52d) should be reclassified as a new Dooley variety, after the provenience of the specimen illustrated. The justification for this is Phillips' (1970:26) rule of sortability, the basic rule in the type-variety classification system: "Types should be based primarily on criteria that can be identified on sherds of average size, i.e., on features of paste, surface, and decorative technique, as little as possible on form and design." According to this same rule, the flared-rim jars with crosshatchedincised rims and brushed bodies that are now classified as Maydelle Incised (Suhm and Jelks 1962:103 and Plate 52c) should be reclassified as a Harrison Bayou Incised var. Riley. ${ }^{27}$ Rim sherds of such pots are unsortable from Harrison Bayou Incised, and some of them are certainly among the many rim sherds now misclassified as "Canton Incised". 
Volume $9(3 / 4)$

\section{Reinterpreting the So-Called Sanders Phase Ceramics of Northeast Texas and Southeast Oklahoma}

So by modern standards for ceramic classification, only 15 of the 132 sherds from the middens at Sanders which Krieger classified as "Canton Incised" exhibit the same decoration as the two "Canton Incised" pots in the Sanders mortuary assemblage. Only those should have been classified originally as Canton Incised or, as I now classify them, Avoyelles Punctated var. Canton (Table 5). The other 117 , which include 88 sherds of Mazique Incised, 22 of Harrison Bayou Incised, and eight untypable punctated sherds, are sherds he could only have included in Canton Incised because of their obvious stylistic similarity to the two pots from the graves. Certainly, he knew he had no contextual evidence that they were contemporaneous, and he had no good reason to assume they were, because he knew $(1946: 201,265)$ the middens at Sanders were multiple component deposits representing a long occupation.

If the redoubtable An Introductory Handbook of Texas Archeology (Suhm, et al. 1954) had never been published, Krieger's classification of this pottery would have had little affect on Texas and Oklahoma archeology because he illustrated no sherds of Canton Incised in the Sanders report, just the two pots. Nor did he describe the type carefully enough to reveal the range of variation he had gratuitously attributed to it $(1946: 190)$. Therefore, readers of that description would have assumed that the 132 "fragmentary vessels ${ }^{128}$ of Canton Incised he reported from the middens at Sanders were very similar to the two whole pots from the graves, in which case very little "Canton Incised" pottery would have been identified at other sites over the years. Probably around 147 sherds, as far as the 23 sites besides Sanders at which Bruseth, Wilson, and Perttula have identified probable Sanders phase components are concerned (Table 5). And that, I imagine, would have been insufficient to support the "Sanders focus"/"Sanders phase" concept the way it has been supported by the distribution of the pottery that has been misclassified all these years as Canton Incised.

But the future of the Sanders focus as a bogus taxon was assured eight years later when An Introductory Handbook of Texas Archeology was published. There, ignoring his own (1946:201,265) admonition that "a Sanders Focus must be based primarily on the series of 21 graves and associated traits" from Sanders, Krieger and his associates codified his overly inclusive classification by including descriptions and illustrations of sherd $\mathrm{s}^{29}$ of Mazique Incised and Harrison Bayou Incised from the multiple component (Brown 1996:402, Story 1991:17) middens at Sanders in the description of Canton Incised (Suhm and Jelks 1962:23 and Plate 12, Suhm, et al. 1954:254 and Plate 10). And, as Table 5 shows, archeologists working in northeast Texas and southeast Oklahoma have been dutifully misclassifying sherds of these types as 
Canton Incised ever since.

They have also been misclassifying as Canton Incised sherds of other punctated and incised types that occur in northeast Texas and southeast Oklahoma. The small collection of 15 punctated and incised sherds from the Yarbrough site is suspect in this regard because one of the two illustrated sherds with this design is obviously a Pennington Punctated-Incised rim sherd (Johnson 1961:Fig. 23e). The much larger collection reported from the Taddlock site ( 758 sherds) and the smaller ones from Spoonbill and Hines are suspect for the same reason that the "Sanders Engraved" pottery from these sites is suspect. The "Canton Incised" from these sites is not pottery that conforms to the type description, as loose as it is, but pottery that Bruseth and Perttula assigned to another of their ad hoc "element categories" which are "based only on design elements, without regard for temper, vessel form, and other attributes commonly included in typological classification." This one includes all sherds with parallel diagonal incised lines, diagonal incised lines and punctations, crosshatched incised lines, and "miscellaneous crosshatched incised elements." It could, and probably does, include sherds of every incised and punctated type known to occur in northeast Texas, namely Crockett Curvilinear Incised, Dunkin Incised, Haley Complicated Incised, Harrison Bayou Incised, Kiam Incised, Maydelle Incised, Pease Brushed Incised, Pennington Punctated-Incised, and Weches Fingernail Impressed.

Whole pots of other types have also been misclassified as Canton Incised. In the manuscript report on which Bruseth, Wilson, and Perttula's (1995:Table 1) original identification of the Holdeman site as one with a probable Sanders phase component is based, Perino (1985) identified two shouldered jars with strap handles and applique festoons on the body (Perino, 1995:Figure 23A and B) as "identical medium-sized Canton Incised jars." He seems to have based this identification on the diagonally incised line decoration on the rims of these jars regardless of the fact that strap handles, applique decoration and the shouldered jar form are not attributes of Canton Incised (Suhm and Jelks 1962:23 and Plate 12). Needless to say, perhaps, most rim sherds of this presently unnamed but evidently fairly common northeast Texas utility ware type would probably be misclassified as Canton Incised too.

Allowing for this "misclassification factor" across the board, I estimate (Table 6) that only between 9 and $12 \%$ (between 147 and 193) of the 1559 sherds classified as Canton Incised in the literature on the 24 sites and parts of sites on Bruseth, Wilson, and Perttula's original list came from pots like the two in the Sanders mortuary assemblage, i.e., pots I would classify as Avoyelles Punctated var. Canton. So Canton Incised, the pottery type upon which Perttula and his colleagues tend to base their identifications of "probable" Sanders phase components, is an artifact of the uncritical acceptance, and sometimes idiosyncratic usage, of an antiquated ceramic typology that (perhaps unconsciously, perhaps not) was biased by its creator, Krieger, to do exactly what 
Table 6. Estimated incidences of Avoyelles Punctated var. Canton, Sanders Engraved, Maxey Noded Redware, Monkstown Fingernail Impressed and Sanders Plain at "Sanders focus" sites*.

\begin{tabular}{|c|c|c|c|c|c|c|c|c|}
\hline Sites & $\begin{array}{l}\text { Avoyelles } \\
\text { Punctated. } \\
\text { var. Canton } \\
\end{array}$ & $\begin{array}{l}\text { Sanders } \\
\text { Engraved }\end{array}$ & $\begin{array}{l}\text { Maxey } \\
\text { Noded }\end{array}$ & $\begin{array}{l}\text { Monkstown } \\
\text { Fingernail } \\
\text { Impressed } \\
\end{array}$ & $\begin{array}{l}\text { Sanders } \\
\text { Plain }\end{array}$ & $\begin{array}{l}\text { Sherds of } \\
\text { Sanders } \\
\text { types }\end{array}$ & $\begin{array}{l}\text { Sherds of } \\
\text { all types }\end{array}$ & $\begin{array}{l}\% \text { sherds of } \\
\text { Sanders types }\end{array}$ \\
\hline A. C. Mackin & 0 & 0 & 1 & 0 & $?$ & 1 & 2357 & .04 \\
\hline Baldwin & 0 & 0 & 5 & 0 & 7 & 12 & 1294 & 9 \\
\hline Beaver & present & 7 & 8 & 0 & $?$ & 15 & 5347 & .2 \\
\hline Bell & 0 & 5 & 0 & 0 & 1 & 6 & 766 & .7 \\
\hline Clement & 0 & 0 & 0 & 0 & 0 & 0 & 0 & 0 \\
\hline Cook & $1 ?$ & 0 & 0 & 0 & 0 & 0 & 62 & 0 \\
\hline E. Johnson & $\begin{array}{l}\text { "a few } \\
\text { sherds" }\end{array}$ & 12,2 pots & 4 & 0 & 41 & 57,2 pots & 5690 & 1 \\
\hline Fasken & 0 & 0 & 0 & 0 & 0 & 0 & 0 & 0 \\
\hline Gregory & present (8?) & 0 & 0 & 0 & 1 & 1 & 430 & .2 \\
\hline Harling & present? & 0 & 0 & 0 & 0 & 0 & 0 & 0 \\
\hline Hines & 0 & 4 & 0 & 0 & 0 & 4 & 1378 & .2 \\
\hline Holdeman & 2 pots & 0 & 3 pots & 0 & 0 & 5 pots & n. a. & n. a. \\
\hline Kaufinan, E. Md. & 4 & 1 & 0 & 0 & 14 & 19 & 1076 & 2 \\
\hline Mahaffey & present?, $37 ?$ & 0 & 0 & 1 & 13 & 14 & 1502 & 9 \\
\hline Nelson & 21 & 0 & 3 & 0 & 23 & 47 & 598 & 8 \\
\hline Pat Boyd & 10 & 9 & 18 & 0 & 38 & 75 & 4668 & 2 \\
\hline Payne & 0 & 0 & 0 & 0 & 47 & 47 & 6676 & .7 \\
\hline Pine Creek & 0 & 0 & 0 & 0 & $?$ & 0 & 505 & 0 \\
\hline Roitsch & 0 & 0 & 0 & 0 & 0 & 0 & 0 & 0 \\
\hline Spoonbill & 2 & 12,1 pot & 0 & 0,2 pots & 0 & 14,3 pots & 2584 & .5 \\
\hline Taddlock & 95 & 305 & 0 & 0 & 0 & 400 & 18,605 & 2 \\
\hline T. Moody & 0 & 0 & 0 & 0 & 0 & 0 & 0 & 0 \\
\hline Woods Md. & 0 & 0 & 0 & 0 & 0 & 0 & 2208 & 0 \\
\hline Yarbrough & 15 & $45,1 \mathrm{pot}$ & 0 & 1 & 0 & 61,1 pot & 612 & 9 \\
\hline Totals & $\begin{array}{l}147+193 \\
\text { sherds, } \\
2 \text { pots }\end{array}$ & $\begin{array}{l}400 \text { sherds, } \\
4 \text { pots }\end{array}$ & $\begin{array}{l}39 \\
\text { sherds; } \\
3 \text { pots }\end{array}$ & $\begin{array}{l}2 \text { sherds } \\
2 \text { pots }\end{array}$ & 185 sherds & $\begin{array}{l}773.819 \\
\text { sherds; } \\
11 \text { pots }\end{array}$ & $\begin{array}{l}56,358 \\
\text { sherds }\end{array}$ & 1 \\
\hline Sanders site: & & & & & & & $\begin{array}{l}\text { sherds / } \\
\text { pots }\end{array}$ & sherds/pots \\
\hline $\begin{array}{l}\text { sherds from } \\
\text { middens }\end{array}$ & 15 & 52 & 22 & 19 & 162 & 270 & $(02,200$ & @1 $2 \%$ \\
\hline $\begin{array}{l}\text { pots from buriats } \\
\text { and trenches }\end{array}$ & 2 pots & 21 pots & 12 pots & 3 pots & 15 pots & 53 pots & 74 pots & $72 \%$ \\
\hline
\end{tabular}

* Provenience data on pots from Sanders are from the Sanders site archives, TARL. Identifications of the Holdeman site pots are based on my examination of the collection. 
it has done: produce spurious ceramic evidence of "Sanders focus" or "Sanders phase" occupations at dozens of sites in northeast Texas and southeast Oklahoma, sites at which - let us keep in mind there is no other evidence of such occupations.

\section{Reinterpreting the "Probable Sanders Phase Components" Identified by Bruseth and Perttula}

My reclassification of "Canton Incised" pottery into three utility ware types and my critical review of the distribution of the types Sanders Engraved, Maxey Noded Redware and Monkstown Fingernail Impressed in northeast Texas and southeast Oklahoma support the following reinterpretation of the 23 sites with socalled Sanders phase components listed by Perttula and his colleagues.

Disregarding the reported figures for Sanders Plain because, as Perttula and others (Bruseth 1998:58, Perttula 1986: 485-486, Perttula and Skiles 1995:4) have noted, it is too often misidentified to be useful as a marker type, nine of these sites (Clement, Fasken, Harling, Holdeman, Payne, Pine Creek, Roitsch, T. Moody and Woods Mounds) are without acceptable published evidence of "Sanders phase" pottery types. Recalling the absence at these sites of all putative Sanders focus diagnostics except pottery, there is no reason to list them as sites with "probable" Sanders phase components, although some of them may have been occupied while the Sanders entrepot was in use.

Eight of the remaining 14 cannot be taken seriously as sites with "probable," or even possible, "Sanders phase" compo- nents either, even though they have reportedly yielded sherds or pots of what should be the major "Sanders phase" decorated types (Sanders Engraved, Maxey Noded Redware, and Monkstown Fingernail Impressed), because the numbers of specimens of these types are too small, relatively and absolutely. Two other explanations for their reported occurrences at these sites are more probable. Some are misidentified specimens of local Caddo types. Others are pots or sherds from pots obtained by local Caddo people through trade or other kinds of contact with the Spiroans at the Sanders entrepot. These sites are: A. C. Mackin, with one reported sherd of Maxey Noded Redware; Baldwin with five; Bell with five reported sherds of Sanders Engraved; Cook with one possible sherd of Avoyelles Punctated var. Canton; Gregory with a possible eight; Hines with four sherds of Sanders Engraved; Holdeman with two Avoyelles Punctated var. Canton pots and three Maxey Noded Redware bottles; and Mahaffey with up to 37 sherds of Avoyelles Punctate var. Canton and one reported sherd of Monkstown Fingernail Impressed.

This leaves six sites, of the original 23 , at which the reported numbers of decorated 
sherds or pots of so-called Sanders phase types are large enough to admit the possibility of some kind of "Sanders phase" component, as Bruseth, Wilson, and Perttula would have it. Or, as I would have it, some kind of link with the Spiroan component at the Sanders site. These are the Beaver, E. Johnson, Nelson, Pat Boyd, Spoonbill, Taddlock, and Yarbrough sites, three of which - Taddlock, Spoonbill, and Yarbrough - I have already rejected because the classification of the so-called Sanders phase pottery types reported for them is unacceptably idiosyncratic.

The Beaver and E. Johnson ceramic collections contain enough sherds of socalled Sanders phase types to raise the possibility (assuming they are all correctly identified) of some kind of Sanders focus/ phase connection. Nevertheless, considering the absence of other Sanders focus/ phase traits and the absence of contextual data, they are not numerous enough to support the identification of "probable" Sanders phase components. Again, in terms of my Spiroan entrepot hypothesis, the more reasonable conclusion would be that this pottery represents trade with the Spiroans at Sanders.

Two sites are left, Pat Boyd, and Nelson. The collections from Pat Boyd contain significant quantities of "Canton Incised," Sanders Engraved, and Maxey Noded Redware. Yet, although this is one of the sites Krieger (1946:172) named in his original description of the Sanders focus, this is not pottery either he or Perttula and his colleagues could claim as diagnostic of a Sanders focus, or Sanders phase, occupation. Contrary to the dogma laid down by Krieger (1946:186) that "Shell tempering is quite absent" at Sanders focus sites, and reaffirmed by themselves (Bruseth, et al. 1995:226), a substantial amount of it is reported to be shell tempered. This includes, according to Rohrbaugh (1973:80, 86, 88 and Figure 3 ), at least $28 \%$ of the 252 sherds he classified as Sanders Plain, 23\% of the 284 he classified as Canton Incised, and an unspecified number of the 18 he classified as Maxey Noded Redware. Furthermore, in three features, two pits and a house floor (Rohrbaugh 1973:131134), clay tempered sherds of these types were found intermixed with substantial numbers of sherds Rohrbaugh classified as Woodward Plain, Woodward Plain being the shell-tempered type diagnostic of Spiro phase occupations in the Arkansas Valley (Brown 1971:141-146).

Thus, the Pat Boyd assemblage is inexplicable in terms of Krieger's Sanders focus hypothesis. But it is easily explained in terms of my Sanders entrepot hypothesis. As Bruseth, Wilson, and Perttula (1995:228) note, I have argued (1993a:203) that the plain shell-tempered pottery from the middens at Sanders, pottery Krieger relegated - improbably, considering the location of the site - to later occupations by Plains peoples, would be as much at home in an intrusive Spiro phase assemblage as a Plains assemblage $^{30}$. Considering both the assemblage and the location (Figure 2) of the site - it is on the Kiamichi, directly on the probable riverine/overland route between Spiro and Sanders (Schambach 1995:Figure 4) - I interpret the Pat Boyd data as evidence of one of the way stations that, as I hypothesized some time ago (1995:14 n.4), must have existed along the 
150 mile-long Spiroan traders' trail between Spiro and the Sanders site. For similar reasons, I consider the Nelson site assemblage evidence of yet another of these way stations.

\section{Summary and Conclusions}

The disagreement between Perttula, his colleagues, and me over the interpretation of the Sanders mortuary assemblage is not the result of my "limited scrutiny" of (Perttula 1997b:16), or of my "ignor[ing] and/or selectively exploit[ing]" (Bruseth, et al. 1995), the archeological record of northeast Texas and southeast Oklahoma. It is the result of their misunderstanding and misuse of the phase concept and of their uncritical, idiosyncratic, usage of an antiquated, provincial, ceramic typology tailored to support Krieger's erroneous interpretation of the Sanders mortuary assemblage as a Caddoan assemblage, an interpretation based on his deference to the doctrinaire opinion of James B. Griffin rather than his basically correct original impression that it is Mississippian.

Their newly formulated "Sanders phase" is not a phase but a period misnamed a phase, a taxonomically bizarre and archeologically useless entity that neither contradicts my interpretation of its ostensible type assemblage, the Sanders mortuary assemblage; nor offers a better one; nor supports Krieger's original interpretation. Instead, the Sanders site, long considered the key site in the traditional paradigm for Caddo area archeology and recently described as "unquestionably one of the more important archeological sites" in northeast Texas and southeast Oklahoma (Story, et al. 1990:302), the site - moreover - that produced the second largest hoard of Mississippian prestige goods found west of the Mississippi, is marginalized and cavalierly dismissed as "apparently rather unique," "less than "typical" and "on the periphery" of the Caddo area (Bruseth and Perttula 1981:6, 89). To Brueseth, Wilson, and Perttula $(1995: 230)$ it is merely a site in a "much larger regional Caddoan cultural tradition in southeastern Oklahoma and northeastern Texas" that "has gained notoriety largely because it happened to have been one of the earliest sites excavated in northeast Texas ... and because Krieger . . . used it to help establish the Sanders 'focus' as well as the overall GibsonFulton Caddoan framework."

I think not. My model for the Middle Caddo period archeology of the Red River Valley in northeast Texas and southeast Oklahoma includes two interacting populations. A small population of Spiroan bow traders from the Arkansas Valley maintained an entrepot at Sanders and traveler's way-stations at Nelson, Pat Boyd, and - no doubt - other sites along the route between the Sanders and Spiro sites. The local Red River Valley Caddo population supplied expertly made Osage orange bows to the Spiroans in exchange for the imported goods, including Mississippian pottery of the types Sanders Engraved, Maxey Noded Redware, 
Volume $9(3 / 4)$

Monkstown Fingernail Impressed and Sanders Plain, which appear occasionally at Red River Caddo sites.

For reasons given above and elsewhere, I classify the archeological evidences of the activities of the Spiroan traders at Sanders and other sites as Spiro phase, not Sanders phase, materials. Because of the Sanders focus/Sanders phase red herring, the archeological remains of the local Caddo population, whose ceramic assemblage probably included the decorated utility ware types Harrison Bayou Incised var. Harrison Bayou, Mazique Incised var. Mazique, and Avoyelles Punctated var. Canton, have yet to be isolated and properly classified. Should anyone do so, a prospect that seems remote given the mind set of archeologists now working in this area, the name "Sanders" cannot be attached to any taxa that might be formulated. That name must be relegated to the history of Caddo area archeology along with Krieger's defunct Sanders focus hypothesis. Years ago (as noted above), when they seem to have had a less idiosyncratic approach to archeological taxonomy then they do now, Bruseth and Perttula (1981:141-142) assigned the materials from the Spoonbill, Taddlock, and Hines sites which are now assigned to their "Sanders phase" to a newly formulated "Pecan Grove" phase. They have since abandoned that taxon without explanation (Story et al. 1990:173). It might be appropriate to revive it as a designator for the local Caddo population with which the Spiroans were interacting.

\section{Acknowledgments}

Thanks to Darrell Creel for permission to study and photograph the Sanders collection and other materials at the Texas Archeological Research Center in Austin. Thanks to Mary Herron for permission to do the same with the Holdeman site collection at the Museum of the Red River in Idabel, Oklahoma. Thanks to Mark Walters for permission to photograph the extensive collection of pots obtained by his father from various sites in northeast
Texas, and for bringing parts of the collection to my lab for study. Thanks to Michael Evans and Jami Lockhart of the Arkansas Archeological Survey's Coordinating Office in Fayetteville for technical assistance in creating Figures 1 and 2 . And thanks to Donna McCloy, reference librarian at Southern Arkansas University, for processing countless interlibrary loan requests. 


\section{References Cited}

Bastian, T.

1966 Initial Report On The Longest Site. Great Plains Newsletter 3(1):1-3.

Bell, R. E. and D. A. Baerreis

1951 A Survey of Oklahoma Archaeology. Bulletin of the Texas Archaeological and Paleontological Society 22:7-100.

Brown, J. A.

1971 Spiro Studies, Volume 3: Pottery Vessels. First Part of the Third Annual Report of Caddoan Archaeology -- Spiro Focus Research, The University of Oklahoma Research Institute, Norman.

1984 Arkansas Valley Caddoan: The Spiro Phase. In Prehistory of Oklahoma, edited by R. E. Bell, pp. 241-263. New World Archeological Record, J. B. Griffin, general editor. Academic Press, Orlando.

1991 Comments on Gregory Perino's Holdeman site manuscript. Letter of June 2 on file with Holdeman site data, Museum of the Red River, 812 East Lincoln Road, Idabel, Oklahoma, 74725.

1996 The Spiro Ceremonial Center: the Archaeology of Arkansas Valley Caddoan Culture in Eastern Oklahoma. Memoirs of the Museum of Anthropology,
Number 29, Volumes One and Two. University of Michigan, Ann Arbor.

Brown, K. M.

1975 The Tigert Site: An Early Caddoan Archeological Site in the Hart Creek Drainage, Northeast Texas. Texas Journal of Science XXVI (1-2):229-247.

Bruseth, J. E.

1998 The Development of Caddoan Polities Along the Middle Red River Valley of Eastern Texas and Oklahoma. In The Native Culture History of the Caddo; Their Place in Southeastern Archeology and Ethnography, edited by T. K. Perttula and J. E. Bruseth, pp. 4768. Studies in Archeology, vol. 30. Texas Archeological Research Laboratory, The University of Texas at Austin, Austin.

Bruseth, J. E. and T. K. Perttula

1981 Prehistoric Settlement Patterns at Lake Fork Reservoir. Texas Antiquities Permit Series, Report 2, Texas Historical Commission, Austin.

Bruseth, J. E., D. E. Wilson and T. K. Perttula

1995 The Sanders Site; A Spiroan Entrepot in Texas? Plains Anthropologist 40(153):223-236.

Davis, E. M.

1962a Archaeological Salvage Investi- 
gations of the Harling Mound in Fannin County, Texas. American Philosophical Society Year Book, $1961: 487-489$.

1962b The Harling Site (41FN1), Fannin County, Texas. Plains Anthropologist 7(16):86.

1970 Archaeological and Historical Assessment of the Red River Basin in Texas. In Archeological and Historical Resources of the Red River Basin, edited by H. A. Davis, pp. 25-65. Arkansas Archeological Survey, Research Series No. 1, Fayetteville.

Derrick, S. M. and D. Wilson

1997 Cranial Modeling as an Ethnic Marker among the Prehistoric Caddo. Bulletin of the Texas Archeological Society 68:139-146.

Dillehay, T.

1974 Late Quaternary Bison Population Changes On The Southern Plains. Plains Anthropologist 19:180-196.

Duffield, L. F.

1961 The Limerick Site at Iron Bridge Reservoir, Rains County, Texas. Bulletin of the Texas Archeological Society 30:51-116.

Duffield, L. F, and E. B. Jelks

1961 The Pearson Site: A Historic Indian Village Site in Iron Bridge Reservoir, Rains County, Texas. Department of Anthropology, University of Texas, Archaeology Series 4, Austin.
Early, A. M.

1988 Standridge: Caddoan Settlement in a Mountain Environment. Arkansas Archeological Survey Research Series 29, Fayetteville.

1993 Ceramics. In Caddoan Saltmakers in the Ouachita Valley, edited by A. M. Early, pp. 63-144. Arkansas Archeological Survey Research Series 43, Fayetteville.

Farney, D.

1980 The Tallgrass Prairie: Can It Be Saved? National Geographic 157(1):37-61.

Fenneman, N. M.

1938 Physiography Of Eastern United States. McGraw-Hill, New York and London.

Flynn, P.

1976 A Study of Red-Filmed Pottery from the Clement Site (Mc-8), McCurtain County, Oklahoma. Bulletin of the Oklahoma Anthropological Society 24:127134.

Ford, J. A.

1936 An Analysis of Indian Village Site Collections form Louisiana and Mississippi. Louisiana Geological Survey, Anthropological Study 2, Baton Rouge.

Gettys, M.
1975 Preliminary Report on Archeological Investigations at Lukfata Reservoir, Southeastern Oklahoma. General Survey Report 
No.14, Oklahoma River Basin Survey Project. University of Oklahoma, Office of Research Administration, Norman.

Granberry, D.

1995 William T.McKenzie Mound. The Record, an Occasional Publication of the Dallas Archeological Society 46(Number 1):ii- 18 .

Griffin, J. B.

1941 Comments on: "The Pottery of the Sanders Farm, Lamar County, Texas," by Alex D. Krieger. Letter of July 26, on file, Sanders site archives, Texas Archeological Research Laboratory, Austin.

1952 Prehistoric Cultures of the Central Mississippi Valley. In Archeology of Eastern United States, edited by J. B. Griffin, pp. 226-238. University of Chicago Press, Chicago.

Johnson, L., Jr.

1961 The Yarbrough and Miller Sites of Northeastern Texas, With a Preliminary Definition of the $\mathrm{La}$ Harpe Aspect. Bulletin of the Texas Archeological Society 32:141-284.

Kelley, D. B. (editor)

1997 Two Caddoan Farmsteads In The Red River Valley: The Archeology Of The McLelland And Joe Clark Sites. Arkansas Archeological Survey Research Series 51, Fayetteville.
Kelley, D. B., D. G. Hunter, P. S. Gardner, D. C. Weinand, A. Tine and L. L. Tiezen 1996 The McLelland and Joe Clark Sites: Protohistoric-Historic Caddo Farmsteads in the Red River Valley of Northwest Louisiana. Southeastern Archaeology 15(1):81-102.

Krieger, A. D.

1941 "The Pottery of the Sanders Farm, Lamar County, Texas." Unpublished manuscript on file, Sanders site archives, Texas Archeological Research Laboratory, Austin.

1946 Culture Complexes and Chronology In Northern Texas With Extensions of Puebloan Dating To The Mississippi Valley. Publication 4640, University of Texas, Austin.

Lynott, M. J.

1980 Prehistoric Bison Populations Of Northcentral Texas. Bulletin of the Texas Archeological Society 50:89-101.

Martin, W. A.

1991 Roitsch Site (formerly Sam Kaufman site). Texas Archeology 35(3):8-9.

1992 The Roitsch Site (41RR16). Texas Archeology 36(3):8-10.

Newell, H. P. and A. D. Krieger

1949 The George C. Davis Site, Cherokee County, Texas. Memoirs Of The Society For American Archaeology Number 5. Published 
Volume $9(3 / 4)$

Jointly by the Society for American Archaeology and The University of Texas Press, Menasha.

Perino, G.

1985 "Holdeman Site Report (41RR11); Rough Draft." Manuscript on file, Museum of the Red River, 812 East Lincoln Road, Idabel, Oklahoma, 74745.

1995 The Dan Holdeman Site (41RR11), Red River County, Texas. Journal of Northeast Texas Archaeology 6((1995)):3-65.

Perttula, T. K.

1986 Appendix 4: Prehistoric Ceramic Materials. In This Everlasting Sand Bed: Cultural Resources Investigations at the Texas Big Sandy Project, Wood and Upshur Counties, Texas, edited by P. T. K., S. B. D, C. M. B, T. M. C and V. F. Jr., pp. 481-496. Reports of Investigations Number 52. Prewitt and Associates Inc., Austin.

1995a A Reconsideration of The Chronological And Cultural Placement of The Mortuary Remains And Grave Goods From The Dan Holdeman Site. Journal of Northeast Texas Archaeology 6(1995):67-87.

1995b The Taddlock Site. In Collected Papers on Caddoan Archaeology In The Upper Sabine River Basin, Northeastern Texas, edited by $\mathrm{T}$. K. Perttula, pp. 29-34. Special
Publication No. 1 (1995). Friends of Northeast Texas Archaeology.

1997a The Archaeology of the Middle Caddoan Period in the Middle Red River Valley of Northeast Texas. Journal of Northeast Texas Archaeology 10:47-51.

1997b Sabine River and Middle Red River Ceramics: Musings on the Ceramic Data Used in Schambach's "Continuing the Discussion of the Spiroans and Their Entrepots". Caddoan Archeology 8(3):9 - 18.

Perttula, T. K. and K. K. Gilmore

1988 Archaeological Survey Along Mill Creek and Tributaries, Wood County, Texas: 1984-1988. Contributions in Archaeology No.6, Institute of Applied Sciences. University of North Texas, Denton.

Perttula, T. K., K. K. Gilmore, P. McGuff and B. D. Skiles

1988 Archeological Survey and Testing Along Mill Race Creek and Tributaries, Wood County, Texas: In Search Of The French Trading Post Le Dout. Texas Archeology 32(1):7-8.

Perttula, T. K., M. R. Miller, R. A. Ricklis, D. J. Prikryl and C. Lintz

1995 Prehistoric and Historic Aboriginal Ceramics inTexas. Bulletin of the Texas Archaeological Society 66:176235. 
Perttula, T. K. and B. D. Skiles

1995 41RA65, An Early Ceramic Early Caddoan Period Site On Garrett Creek, Rains County, Texas. In Collected Papers On Caddoan Archaeology In The Upper Sabine River Basin, Northeastern Texas, edited by $\mathrm{T}$. K. Perttula, pp. 1-14. Friends of Northeast Texas Archaeology, Special Publication No.1 (1995).

Phillips, P.

1970 Archaeological Survey in the Lower Yazoo Basin, Mississippi, 1949-1955. Papers of the Peabody Museum of Archaeology and Ethnology 60 . Harvard University, Cambridge.

Phillips, P., J. A. Ford and J. B. Griffin 1951 Archaeological Survey In The Lower Mississippi Alluvial Valley, 1940-1947. Kraus Reprint, 1968 ed XXV. Papers Of The Peabody Museum Of American Archaeology and Ethnology, Harvard University, Vol. XXV, Cambridge, Massachusetts.

Prikryl, D. J.

1991 Fasken Mounds. Texas Archeology 35(3):1-6.

1992 Fasken Mounds. Texas Archeology 36(3):10-12.

Quimby, G. L.

1951 The Medora Site, West Baton Rouge Parish, Louisiana. Publication 664. Field Museum of Natural History, Chicago.
Rohrbaugh, C. L.

1973 Hugo Reservoir III: A Report on the Early Formative Cultural Manifestations in Hugo Reservoir and in the Caddoan Area. Archaeological Site Report No. 24, Oklahoma River Basin Survey, University of Oklahoma Research Institute, Norman.

1982 Spiro and Fort Coffee Phases: Changing Cultural Complexes of the Caddoan Area. Ph.D. dissertation, Graduate School of the University of WisconsinMadison, University Microfilms, Ann Arbor.

Schambach, F. F.

1981 A Description and Analysis of the Ceramics. In The Shallow Lake Site and Its Place in Regional Prehistory, edited by M. A. Rolingson and F. F. Schambach, pp. 101-176. Arkansas Archeological Survey Research Series 12, Fayetteville.

1990a The Northern Caddoan Area Was Not Caddoan. Caddoan Archeology Newsletter 1(4):2-5.

1990b The Place of Spiro in Southeastern Prehistory: Is It Caddoan or Mississippian. Southeastern Archaeology 9(1):67-69.

1991 A Critique of Oklahoma Archeology. The Arkansas Archeologist, Bulletin of the Arkansas Archeological Society 30:57-69. 
1993a Some New Interpretations of Spiroan Culture History. In Archaeology of Eastern North America: Papers in Honor of Stephen Williams, edited by J. B. Stoltman, pp. 187-230. Archaeological Report No. 25. Mississippi Department of Archives and History, Jackson.

1993b Spiroan Entrepots at and Beyond the Western Border of the TransMississippi South. Caddoan Archeology Newsletter IV(2):1126.

1994a The Great Osage Orange Expansion and Its Implications for Our Understanding of the Mississippian Interaction Sphere. Paper presented at a joint meeting of the 51st Southeastern Archaeological Conference and the 39th Midwest Archaeological Conference, Lexington.

1994b A Probable Spiroan Entrepot in the Red River Valley in Northeast Texas. Poster presentation, 59th Annual Meeting of the Society for American Archaeology, Anaheim.

1994c A Probable Spiroan Entrepot in the Red River Valley in Northeast Texas. Poster presentation, 36th Caddo Conference, Fayetteville, Arkansas.

1994d A Spiroan Trader's Trail On The Western Border Of The Southeast. Paper presented at a joint meeting of the 51st Southeastern Archaeological Conference and the 39th Midwest Archaeological Conference, Lexington.

1995 A Probable Spiroan Entrepot in the Red River Valley in Northeast Texas. Caddoan Archeology Newsletter 6(1):9-25.

1996 The Womack, Gilbert and Pearson Sites: Early Eighteenth Century Tunican Entrepots in Northeast Texas? Caddoan Archeology $7(3): 9-31$.

1997a Continuing the Discussion of the Spiroans and Their Entrepots: A Reply to Brooks's Critique of My New Paradigm for the Archeology of the Arkansas Valley. Caddoan Archeology 7(4):17-46.

1997b Review of "The Spiro Ceremonial Center: The Arkansas Valley Caddoan Culture in Eastern Oklahoma, by James A. Brown, with a foreword by James B. Griffin. American Antiquity 62(3): 571-572.

Schambach, F. F. and J. E. Miller

1984 A Description and Analysis of the Ceramics. In Cedar Grove: An Interdisciplinary Investigation of a Late Caddo Farmstead in the Red River Valley, edited by N. L. Trubowitz, pp. 109-170. Arkansas Archeological Survey Research Series 23, Fayetteville.

Schambach, F. F. and D. B. Waddell 1990 The Pottery from the Bangs Slough Site. In Coles Creek and Mississippi Period Foragers In 
The Felsenthal Region of The Lower Mississippi Valley: Evidence From The Bangs Slough Site, Southeast Arkansas, edited by F. F. Schambach, pp. 19-62. Arkansas Archeological Survey Research Series 39, Fayetteville.

Shaw, J. H. and M. Lee

1997 Relative Abundance of Bison, Elk, And Pronghorn on The Southern Plains, 1806-1857. Plains Anthropologist 42(159, Memoir 29):163-172.

Skinner, S. A., R. K. Harris and K. M. Anderson

1969 Archaeological Investigations At The Sam Kaufman Site, Red River County, Texas. Southern Methodist University Contributions in Anthropology No. 5, Dallas.

Smith, B. D.

1984 Mississippian Expansion: Tracing The Historical Development Of An Explanatory Model. Southeastern Archaeology 3(1):13-32.

Story, D. A.

1978 Some Comments On Anthropological Studies Concerning The Caddo. In Texas Archeology; Essays Honoring R. King Harris, edited by K. D. House, pp. 46-68. Institute For The Study Of Earth and Man; Reports of Investigations: 3, C. C. Albritton, general editor. SMU Press, Dallas.

1991 Some Comments on the Status of Caddoan Archaeology. News and Views, Newsletter of the
Department of Archeological Planning and Review, Texas Historical Commission 3:17-18.

Story, D. A., J. A. Guy, B. A. Burnett, M. D. Freeman, J. C. Rose, D. G. Steele, B. W. Olive and K. J. Reinhard

1990 The Archeology and Bioarcheology of the Gulf Coastal Plain: Volume 1. Arkansas Archeological Survey Research Series 38, Fayetteville.

Suhm, D. A. and E. B. Jelks

1962 Handbook of Texas Archeology: Type Descriptions. Special Publication Number One. The Texas Archeological Society, Austin.

Suhm, D. A., A. D. Krieger and E. B. Jelks

1954 An Introductory Handbook of Texas Archeology. Texas Archeological Society Bulletin No. 25, Austin.

Thurmond, J. P.

1990 Archeology of the Cypress Creek Drainage Basin, Northeastern Texas and Northwestern Louisiana. Studies in Archeology No. 5. Texas Archeological Research Laboratory, University of Texas, Austin.

Webb, C. H.

1958 A Review of Northeast Texas Archeology. Bulletin of the Texas Archeological Society 29:25-62.

1963 The Smithport Landing Site: An Alto Focus Component in DeSoto 
Volume $9(3 / 4)$

Parish, Louisiana. Bulletin of the Texas Archeological Society 34:143-187.

1983 The Bossier Focus Revisited: Montgomery I, Werner and Other Unicomponent Sites. In Southeastern Natives and Their Pasts; Papers Honoring Dr. Robert E. Bell, edited by D. G. Wyckoff and J. L. Hoffman, pp. 183-240. Oklahoma Archeological Survey Studies in Oklahoma's Past 11, Norman.

Webb, W. P.

1981 The Great Plains. 1981 reprint, originally published in $1931 \mathrm{ed}$. Bison Books, University of Nebraska Press, Lincoln and London.

Willey, G. R. and P. Phillips

1962 Method and Theory in American Archaeology. University of Chicago Press, Chicago.

Wyckoff, D. G.

1967a The E. Johnson Site and Pre- history in Southeast Oklahoma. Archeological Site Report No. 6, Oklahoma River Basin Survey. University of Oklahoma Research Institute, Norman.

1967b Woods Mound Group; A Prehistoric Mound Complex in McCurtain County, Oklahoma. Miscellaneous Report No.1. Oklahoma River Basin Surveys, University of Oklahoma Research Institute, Norman.

1971 The Caddoan Cultural Area: An Archeological Perspective. Oklahoma Archeological Survey, University of Oklahoma, Norman.

1984 The Cross Timbers: An Ecotone in Historic Perspective. In Contributions to Cross Timbers Prehistory, edited by P. L. Kawecki and D. G. Wyckoff, pp. 1-19. Studies in Oklahoma's Past. vol. 12. Oklahoma Archeological Survey, Norman.

\section{End Notes}

1.

I have not "corrected" my original "zero" entry for the T. Moody site to include the 484 sherds, including eight sherds of Canton Incised and two of Sanders Engraved, that Perttula (1997b:11) claims were found there. That discrepancy is the result of an error on Bruseth, Wilson, and Perttula's part, not mine. The "T. Moody" site is not mentioned in the reference provided by them (Perttula, et al. 1988) and the reference that Perttula now provides (Perttula and Gilmore 1988) is not available from the publisher or through interlibrary loan.

2.

For synopses of Krieger's career see Davis 1970:32-33, Story 1978:59, and Story et al. 
$1990: 42-48$.

3.

One could say the Sanders site is on the eastern edge of the broad ecotone of alternating, north-south trending bands of savannas and tallgrass prairies that separates the Eastern Woodlands from the Plains, i.e., the Osage Savannah and Cross Timbers biotic district (Wyckoff 1984:2, Fig.1). Or one could say it is on the eastern edge of the southernmost tip of the vast tallgrass prairie ecosystem that once blanketed some 400,000 square miles of midcontinental North America (Farney 1980:43).

But "approximately on the border between eastern forest and open plains" it is not because that "border" was a figment of Krieger's imagination. Apparently he had not visited the site when he wrote his description and analysis of it (1946:273-280). Had he done so, or consulted Fenneman's (1938) Physiography of Eastern United States, or Walter Prescott Webb's 1931 classic, The Great Plains (1981), neither of which is listed in his bibliography, he probably would have realized that he was operating on the basis of an elementary error in Texas geography and the concept of the Sanders focus might have died aborning.

Or perhaps not. It is a matter of record (Suhm, et al. 1954:177) that he did visit it in 1952, at which time he seems to have realized he was wrong about the local geography. In the last formal description of the Sanders focus, which appeared in 1954, the site is no longer described as "facing," or being on the edge of, the "Plains." It is described, more accurately, as being on the edge of a "belt, which is essentially a prairie rather than forest" (Suhm, et al. 1954:176).

But then, in the interest of maintaining the determinist fiction that the location of its various components is what made "Sanders . . . the most divergent of all Caddoan foci" another fiction is introduced, that of Plains "influence," particularly the "influence" of bison and bison hunting. "The culture of Sanders focus," Krieger and his coworkers (Suhm, et al. 1954:176) claimed, "clearly reflects this frontier position between eastern forest and the Great Plains. Bison bones are plentiful in the middens, and artifacts such as hoe blades were fashioned from bison bones; the four-edged beveled knives and stone elbow pipes are other Plains traits not found in Caddo foci except those in Oklahoma in a similar frontier position."

Thus one is invited to envision the Sanders focus as a unique culture of Caddo bison hunters and horticulturists who inhabited the prairie-savannah ecotone on the border between "eastern forest and open plains." Although this seems plausible, it is conjecture based on conjecture. There is no good evidence of bison hunting from the Sanders site and none at all from any of the additional sites Krieger and his co-workers listed - with entirely misplaced confidence - as having Sanders focus components (Suhm, et al. 1954:177). The "bison bones" that Suhm, Krieger and Jelks (1954:176) avowed "are plentiful in the middens" of Sanders focus sites do not exist. Nor do the Sanders focus "middens" in which they were allegedly found. Bison bones have not been reported from any of the sites then thought to 
have Sanders focus components, except Sanders itself, and even there the middens are not "Sanders focus" middens but multiple component middens (Story 1991:17) that might, or might not, contain materials pertaining to the Sanders mortuary assemblage. And of that site Krieger had already written (1946:194): "Aside from scapula hoes, very few bison bones were recovered. No other artifacts of bison bones were found, indicating that the animal, though undoubtedly available in the area, was not hunted to any great extent. The scapula hoes may even have been obtained in trade."

Here Krieger was (again) closer to being right the first time around. As Dillehay (1974:182) has since concluded, "Bison bones seem consistently absent from sites in the present-day wooded areas of East Texas," i.e., from sites located in the woodlands along the eastern edge of the Blackland Prairie. The reason is probably the one adduced by Lynott (1980:92) and Shaw and Lee (1997:169-170). The grasses of the Blackland Prairie, which are the "tallgrasses" of the now largely destroyed tallgrass prairie ecosystem, are not suited to the nutritional needs of bison.

The grasses they favored were the Bluestem-grama, or "shortgrasses," of the plains (see Figure 1). To find bison in significant numbers year-round the inhabitants of the various socalled Sanders focus sites of northeast Texas would have had to travel more than 100 miles up the Red River Valley to the eastern boundary of the Bluestem-grama prairie, the boundary I have designated the "Bison Line" in Figure 1 because it was also the eastern boundary of good bison habitat in Oklahoma.

4.

But, unlike Brown $(1984,1996)$, I consider the Spiro phase a Mississippian rather than a Caddo manifestation (1993a, 1997b).

5.

This is not the first time Bruseth and Perttula have been criticized for what Story (Story et al. 1990:293) calls their "unconventional use of the phase concept." In the example to which she refers they display considerable confusion in the area of time-space systematics by introducing, in a round-about way, the notion that their newly formulated Lone Oak and Pecan Grove "cultural phases" are "part of what has traditionally been termed the Sanders Focus in Northeast Texas"(Bruseth and Perttula 1981:6,87,141). First they establish, "as a heuristic device" three "ceramic phases." Then, after stating - obscurely - that "Ceramic Phases I and II are both part of what has been traditionally been termed the Sanders Focus in Northeast Texas" (Bruseth and Perttula 1981:87), they formulate a "Pecan Grove cultural phase" which, they state (1981:141), "corresponds to "Ceramic Phase II."

More recently, Perttula (1995b) has written in a similar, and similarly confusing, vein: "The occupation at Taddlock dates to the Early Caddoan period, and is associated with the Sanders focus or phase, a cultural entity found in Northeast Texas and Southeast Oklahoma between 
the Sabine and Red River Valleys. . . In the Upper Sabine Basin sites of the Early Caddoan period are included in the Pecan Grove phase, a local manifestation of the Sanders focus or phase."

6.

Notice the circularity of Perttula's (1997a) generalization that "Middle Caddoan Period sites (estimated to date from ca. 1100-1300/1350; see Bruseth et al. 1995) in the Middle Red River Valley of Northeast Texas appear to have cultural affiliation with the Sanders phase/focus originally recognized by Krieger (1946)."

7.

Here I am excluding the T. Moody site. See Note 1.

8.

Closer examination of seven of the entries in the latter two categories would seem to indicate that substandard archeological scholarship compounded of carelessness and wishful thinking is playing a significant role in keeping Perttula and Bruseth's "Sanders phase" afloat. In some cases that appears to be true. Mainly, however, these entries simply indicate how little it takes to identify a "probable component" of a temporally and geographically defined "Sanders phase," and how little this entity is therefore worth archeologically.

The Clement site is the unreported, WPA excavated, type site for the McCurtain focus (Bell and Baerreis 1951:53, Flynn 1976:127, Wyckoff 1967a:8). It is not one of the sites traditionally listed as having Sanders focus components (Suhm, et al. 1954:177, Wyckoff 1971:86) because the only pottery found there is of the shell tempered, late Caddo types Avery Engraved, Simms Engraved, and Flynn's (1976) plain, "red filmed" type, Clement Redware.

I cannot imagine why Bruseth, Wilson, and Perttula think it has a component early enough to fit even their idiosyncratic concept of the Sanders phase, unless a hasty reading of Flynn's description of Clement Redware (which they cite;) suggested to them that it is the red slipped "Sanders focus" type Sanders Plain. Flynn (1976:133) is not as clear about the temper of this type as she should be, but careful reading of her description leaves no doubt that Clement Plain is a shell-tempered type. Thus it could not be Sanders Plain because, according to Krieger's well-known dictum, shell temper is supposed to be "quite absent" in Sanders focus pottery (Krieger 1946:186, Suhm, et al. 1954:179).

The Cook site is one of the two type sites, the other being the nearby Nelson site, for the "Nelson focus," informally defined by Bell and Baerreis (1951:48-53) on the basis of undescribed and mostly unillustrated collections from unpublished WPA excavations in 1936. They considered four pots from graves at one of these sites (they do not say which) "comparable to Sanders Plain of the Sanders focus of Texas" and they reported unspecified 
Volume $9(3 / 4)$

quantities of the Sanders focus pottery types Sanders Engraved, Canton Incised, Monkstown Fingernail Impressed, and Maxey Noded Redware in the sherd collections from both sites. However, they pointedly refrained from assigning them to the Sanders focus because they believed that early Caddo pottery types and other traits not supposed to be associated with that focus were too strongly represented.

Unbeknownst, apparently, to Bruseth, Wilson, and Perttula (1995:Table 1), Rohrbaugh (1973:186-193, Figs. 57 and 58) has restudied both collections. He assigns the Cook site to his early Caddo Apple phase, meaning he agrees with Bell and Baerreis that it is not Sanders focus. That would seem to place it outside the parameters of Bruseth and Perttula's temporally defined "Sanders phase." Perhaps for that reason, Bruseth (1998:58) has conceded that there is no evidence for a "distinct Sanders phase occupation" at the Cook site. Nonetheless, he continues to list it as a site with a "probable Sanders phase" component (Bruseth 1998:59, Table 3-4).

Bruseth, Wilson, and Perttula claim (1995:230) that recent fieldwork by the Texas Archeological Society at the Fasken mound group produced "evidence of a major Sanders phase occupation." To my way of thinking the references they cite, two two-page summaries of the small amount of work done there in 1991 and 1992 (Prikryl 1991, 1992), neither report nor reflect this. Apart from apparently modest quantities of "both Early and Late Caddo potsherds" from various parts of the site, the only artifacts that might be considered indicative of a possible (traditionally defined) Sanders phase occupation are four Bonham points from the fill of Mound A and an unspecified number of otherwise undescribed "Early Caddoan Sanders Plain" sherds from area A (Prikryl 1992:11).

But to their way of thinking these sherds are, apparently, "evidence of a major Sanders phase occupation." If so, I do not see how this position can be reconciled with Perttula's (1995:4) generalization that in the Lake Fork Creek basin of northeast Texas "The identification of Sanders Plain" in an assemblage "need not imply that an A.D. 1200-1400 Sanders phase or Early Caddoan Period II component . . . is present because red slipped plain wares are common from ca. A.D. 900 on. . ." Surely that would apply to the rest of northeast Texas as well.

E. Mott Davis's excavations (1962a:487-489, 1962b:486) in the Harling mound on the west side of Bois d'Arc Creek "a few miles" from Sanders produced no evidence that it was a (traditionally defined) "Sanders phase" structure. He did, however, report that the pre-mound surface yielded "a few sherds," "some" of which were "of a red-filmed ware with clay-grit temper not unlike that found in vessels at the Sanders site." The mound itself was a one-stage structure with plain, shell-tempered sherds in the fill near the top and in intrusive pits. He concluded it was "built no earlier than the time of the Sanders site burials," but understandably, because of the shell tempered pottery - he did not assign it, or the pre mound occupation to the Sanders focus. 
Although Gettys (1975:226) concluded that the Pine Creek site "represents a localized manifestation of the Hochatown Complex in the Glover River area," Bruseth, Wilson, and Perttula (Bruseth, et al. 1995:Table 1) consider it a site with a probable Sanders phase component, and they tentatively list the three untested mounds at the site as Sanders phase as well. Their evidence seems to be 10 plain, slipped, sherds, color unspecified, out of 505 sherds from the site, which Gettys (1975:153) classified as Sanders Plain. That would be insufficient evidence of a traditionally defined "Sanders phase" occupation, even if it were certain that these sherds are Sanders Plain. Considering Perttula's (1995:4) just cited generalization that Sanders Plain" in an assemblage "need not imply that an A.D. 1200-1400 Sanders phase or Early Caddoan Period II component" is present, it should also be insufficient evidence for the presence of a temporally defined "Sanders phase" assemblage.

Bruseth, Wilson, and Perttula (1995:230) state that the "East Mound" at the Arnold Roitsch site is a "Sanders phase" structure. Their sources are two short newsletter accounts by Martin $(1991,1992)$ of the Texas Archeological Society's field school excavations there. In the first, he reports that the excavators hoped to find a "pure" "sealed Sanders phase component" in the "East Mound" (Martin 1991:8). In the second, he reports that the work was stopped by rain before it could be found (Martin 1992:8). Considering the range of pottery types (from French Fork Incised and Coles Creek Incised through Avery Engraved, Nash Neck Banded and Emory Punctate) reported from this mound by earlier excavators (Skinner, et al. 1969:Table 6), the expectation of finding a "pure" traditionally defined Sanders phase component was not realistic. (I can only wonder what a "pure" temporally defined Sanders phase component would be.)

Wyckoff (1967b:66) considered the eight mounds at the Woods site contemporaneous remains of a McCurtain focus occupation. He did not include this site in his list of "sites with occupations relating to the Sanders Focus," published four years later (Wyckoff 1971:86). Nevertheless, Bruseth, Wilson, and Perttula (Bruseth, et al. 1995:Table 1) list one of the Woods site mounds, presumably Mound F, as a "probable Sanders phase" mound. The basis for their contradictory judgement seems to be one radiocarbon date of A.D. 1240 on charcoal from a burned structure reported by Wyckoff (1967b:76). Apparently this is good enough for the identification of a "probable component" of a temporally and geographically defined "Sanders phase."

I trust that they were not misled by the fact that in various places in his report Wyckoff (1967b:55, 58,59) mentioned, for purposes of comparison only, the pottery types Canton Incised, Sanders Plain, Maxey Noded Redware and Sanders Engraved. He did not identify specimens of any of these types in the Woods site collections.

9.

Perttula (1997a) offers a different set of figures, stating: "At the Sanders site, for example, of the 461 classified vessels, Sanders Engraved accounts for 15.8 percent of the assemblage; Canton Incised accounts for 29.1 percent; Maxey Noded Redware accounts for 8.3 percent; 
Volume $9(3 / 4)$

and red-slipped plain bowls (Sanders Plain) comprise another 4.6 percent of the assemblage (Krieger 1946:Table 5)." But, as he should know, there are only 74 whole vessels of these types from Sanders (Krieger 1946:189, Table 6). The other 361 are "fragmentary" vessels, i.e., putative "vessels" based on Krieger's conceit (see Note 28) that he could accurately estimate the number of whole vessels represented by a collection of sherds.

Whether he could or couldn't, the point to be noted here is that these "fragmentary" vessels are represented by sherds (probably, for reasons given in Note 28, not too many than 361 of them) from the middens at the Sanders site. They are not part of the Sanders mortuary assemblage and cannot be used for the definition of Perttula's and Bruseth's "Sanders phase" any more than they could be used for the definition of Krieger's "Sanders focus." As Krieger himself $(1946: 201,265)$ admonished (and regardless of the fact that he ignored his own admonition) that taxon "must be based primarily on the series of 21 graves and associated traits" from Sanders.

10.

In Table 1 I list "Kaufman" and "Roitsch" separately, although the latter is a recently introduced alternate name for the Sam Kaufman site, in order to show how much pottery of so-called Sanders phase types earlier excavators (Skinner, et al. 1969) found in the "East Mound" there.

11.

Perttula's (1997b:11-12) complaint that I have misrepresented the percentages of the types Canton Incised, Sanders Engraved, Maxey Noded Redware and Monkstown Fingernail Impressed at what he calls the "Sabine River sites" (Hines, Spoonbill, Taddlock, and T. Moody) must be read with this in mind. He needs to be reminded that, as I pointed out in the paper to which he is responding (1997a:22), these types have not been identified at these sites; all that has been identified are design element categories that might, or might not, include sherds of these types. They probably do not include very many.

12.

Having examined the bottle in the Walters collection from the Spoonbill site that Perttula (1997b:11) identifies as a "classic Maxey Noded Redware bottle with one row of punctates below the neck", I do not accept his belated announcement that "Maxey Noded Redware is present in the ceramics" he and his colleagues excavated at Taddlock and Spoonbill "although unfortunately the exact number is not quantified" (1997b:11).

This bottle (my research assistant, David Jeane, photographed the Walters collection for me in 1996 and Mark Walters later brought the bottle itself to my lab because of his bemusement over Perttula's identification of it in print as Maxey Noded Redware) is a red on buff specimen that probably belongs to an as yet unnamed Arkansas Valley variety of the Mississippian type Carson Red on Buff. It bears a bold painted design consisting of large 
alternating triangles and rectangles. This combination of decorative treatment and design has no parallels among the Maxey Noded Redware bottles in the type collection from the Sanders site, all of which are red slipped overall, and are of a distinctly different shape as well (Suhm and Jelks 1962:Plate 51, a-e). If Perttula thinks this is a "classic Maxey Noded Redware bottle" there is no telling what he might be including in the "Maxey Noded Redware" he now recognizes in the Taddlock and Spoonbill collections because his concept of the ranges of variation in the attributes of surface finish, decoration, and vessel shape that are permissible for Maxey Noded Redware would have to be much broader than those set forth in the already overly broad (see Note 17) type description.

This would explain why he is confident that there are nine Maxey Noded Redware bottles in the Museum of the Red River collections from the Holdeman site (1997b:10) although when I examined and photographed that collection last December I found only three (see below, Table 4). Considering all of the possibly significant variation that is already subsumed by this type stretching it to include still more is a step backwards into taxonomic chaos.

13.

This is an ad hoc category Perino used - in the original manuscript (1985) of his report on this site - to classify three bottles (see Table 3) he thought resembled Maxey Noded Redware bottles although they lacked the red slipping that is one of the prime diagnostics of that type (Suhm and Jelks 1962:101).

One might imagine - readers of Perino's published report (1995) who have not seen the Holdeman site collection will have to do so because the two bottles referred to there are not illustrated - that this term describes a category of bottles resembling the Maxey Noded Redware bottles from the Sanders site (Suhm and Jelks 1962:Plate 51, specimens A - E) in most significant attributes except red slipping; that is, bottles which could be placed in a easily recognizable unslipped, or gray slipped, companion type of Maxey Noded Redware.

Not so. I was unable to find and photograph the "Maxey Grayware bottle reported for Burial 31 (Table 3; Perino 1985:28) but the two I did find and photograph, those from Burials 37 and 39, resemble the Sanders site bottles in only one attribute each, and that not closely. The Burial 37 specimen consists of part of the body of a small, gray-slipped, globular bottle which had at least three rows of punctations around the neck. Obviously, it is this decorative treatment that reminded Perino of Maxey Noded Redware, and it may even be true that the stimulus for it was a Maxey Noded Redware bottle that the maker of this pot had seen. Nonetheless, type and variety ascriptions must be based on recurring clusters of attributes of manufacture, form, surface finish and decoration in populations of specimens, not assumptions about the significance of one attribute of one incomplete specimen.

The Burial 39 bottle resembles Maxey Noded Redware bottles in that it has a somewhat similar shape (it is broad bottomed, or A-shaped) but there the resemblance ends. It is gray slipped and the upper half of the body is covered with a complex but probably eccentric 
engraved design, the lines highlighted with red pigment. It was accompanied in Burial 39 by a Nash Neck Banded jar (Perino 1995:46), temper unspecified. Since Nash Neck Banded has never been found in association with a Maxey Noded Redware bottle, probably because it came into use after Maxey Noded Redware had gone out of use, the odds are that the resemblance of the Burial 39 bottle to Maxey Noded Redware is spurious.

Unfortunately, Bruseth (1998:58-59 and 64, Note 3) has added to this taxonomic muddle by accepting Perino's "Maxey Grayware" as if it were a properly established type (but getting the name wrong, calling it "Maxey Noded Blackware") and by making it one of the four diagnostic pottery types of his "Sanders phase."

He states, incorrectly, that the term "Blackware" "follows Perino (n.d.), who uses it for a vessel type identical to Maxey Noded Redware except the vessel surface is black." He goes on to say that "Grave offerings associated with Sanders phase interments" at Holdeman "included Maxey Noded Redware/Blackware, Sanders Engraved, and carinated rim and scalloped rim vessels." Having made that misstep, he states (in his argument that the "Nelson focus" should be subsumed in the entity he calls "Sanders Phase Caddoan"): "Only the Nelson site ... shows a distinct Sanders phase occupation, based on the presence of Maxey Noded Redware and Blackware, Canton Incised, and Sanders Engraved sherds." One sentence further on in the same discussion he writes: "The Sanders phase used for this paper is clearly identified with Cluster 3 ceramics (see Table 3-1); these include Canton Incised, Maxey Noded Redware/Blackware, and Sanders Engraved."

14.

I will explain shortly why all but perhaps two of these nine are misclassified specimens of other types whose temporal and cultural relationships with the two "Canton Incised" bowls in the Sanders mortuary assemblage are unknown.

15.

Ironically, appearing as it does in a sentence intended to support Perttula's assertion that this type is "more common at the site than Schambach would have us believe," this is an undocumented assertion. Although someone-Perttula, I presume-has identified as Sanders Plain one specimen shown in the illustrations that accompany Perino's report (1995:Figure 13c), Perino himself did not identify any pots from Holdeman as Sanders Plain. I do not find the name in his report, his manuscript, or in the Museum of the Red River burial forms. If Perttula thinks there are 10 "vessels" of this type among the 73 - or so-plain bowls in the Holdeman collection it is up to him to identify and describe them.

16.

Except that the bottle from Burial 1, an otherwise classic specimen (Perino 1995:Figure 13d) appears to be tempered-I did not have permission, or the equipment, to test it with acid or examine it under high magnification - with fine shell. If so, it probably isn't the only one and 
it probably isn't unusual. According to my observations of November 28, 1995 at the Texas Archeological Research Laboratory in Austin, Pot \# 362, a Maxey Noded Redware bottle from Burial 9 at the Sanders site, is similarly tempered with small white particles that appeared to be shell and they seemed to effervesce when tested with dilute hydrochloric acid. But the particles are so small I couldn't be certain.

17.

The four bottles from sites other than Sanders, specimen "F" from "Wood County," Texas, specimen "G" from the Galt site, Franklin County, Texas, and specimens " $\mathrm{H}$ " and "I" from the Adair site in Garland County, Arkansas (Suhm and Jelks 1962: Plate 51) must be removed from the type description. They were included on the basis of the archeologically unsupported, taxonomically vacuous, assumption that "Bottles from other sites, tend to have continuous fillets, one to three in a set, vertically or diagonally on the body rather than nodes" (Suhm and Jelks 1962:101 and Plate 51). Thus three unattested bottle shapes (Plate 51 , specimens $\mathrm{F}, \mathrm{G}$, and I), one unattested decorative technique, and corpus of misleading distributional data, were added to what is otherwise a remarkably coherent and useful type.

18.

Whatever it is. I could not find this specimen in the Holdeman collection.

19.

See note 17.

20.

This interpretation is supported by Perino's observation that one of the three real Maxey Noded Redware bottles in the Holdeman collection, the specimen from Burial 52, "had a clay repair patch over a crack on the bottom."

21.

Story (Story et al. 1990:331) describes the local sequence as "not very good" and the McCurtain focus - to which many of the pots in these grave lots would now be assigned - as probably a temporal hodgepodge.

22.

Perttula and other critics of my Sanders entrepot hypothesis have yet to acknowledge the existence of, much less come to grips with, the comprehensive and, I think, conclusive bioanthropological evidence that the population associated with the Sanders mortuary assemblage differs significantly from the population represented in the burials from Caddo sites in the Red River Valley in northeast Texas. I refer particularly to the newly developed evidence that the Sanders population exhibits a locally distinct (Derrick and Wilson 1997), Arkansas Valley style (Schambach 1997a:31-32) of annular cranial deformation rather than the tabular style of deformation characteristic of the Caddo population of northeast Texas, southwest Arkansas, and northwest Louisiana. in the Red River Valley. 
Volume $9(3 / 4)$

My explanation for the annularly deformed crania from Historic period graves at the Womack site, located a few miles from Sanders, is presented elsewhere (Schambach 1996).

23.

Most of these are obviously from plowed out graves. However there is no guarantee that all of these were graves traditionalists would classify as Sanders focus, or phase, graves, which is to say graves I would classify as Spiroan.

24.

By this I mean ceramic taxonomy as it has been practiced in the Lower Mississippi Valley and in the Caddo area east of Texas and Oklahoma since 1970 (Early 1988:61-105, 1993:63118, Kelley 1997:36-60, Kelley, et al. 1996:81-102, Phillips 1970:23-238, Schambach 1981:101-176, Schambach and Miller 1984:109-170, Schambach and Waddell 1990:19-62).

25 .

Thus, when found at sites other than Sanders, none of this pottery represents "entrepot trade goods" as Perttula (1997:16) thinks I am suggesting. It is, indeed, too abundant to be anything but locally made pottery, as he rightfully insists.

26.

The grave lot data from the Holdeman site provide indirect evidence that Harrison Bayou Incised var. Harrison Bayou was contemporaneous with the Spiroan usage of the Sanders entrepot. The Harrison Bayou Incised jar from Burial 2 (Perino 1995:Figure 5c), which is misidentified as Maydelle Incised in Perino's manuscript report on the site (1985) and as Canton Incised in Perttula's edited version (Perino 1995:20), was accompanied by one of the two Mound Place Incised var. Albion duck effigy bowls in the Holdeman assemblage. The other (see Table 4) was in Burial 52 where it was accompanied by a Maxey Noded Redware var. Maxey bottle. This type seems to be the best ceramic marker we have for Spiroan activity in the Red River Valley.

Barring the aforementioned possibility that the Maxey Noded Redware bottle from Burial 52 was curated for a lengthy period before it was used as a mortuary offering, this association indicates that the Red River Valley Caddo ceramic assemblage in use while the Spiroans were operating their entrepot at the Sanders site included the local types Harrison Bayou Incised, East Incised, Spiro Engraved, and large, red slipped "Bowie Engraved" bowls. It also included, on evidence from Burial 52, Red River pipes of the Haley variety (Perino 1995:46 and Figure 16a).

27.

According to Thurmond (1990:146), pots classified as Canton Incised and Maydelle Incised are reported from the same grave at the Harold Williams site $(41 \mathrm{CP} 10)$. 
28.

Because Krieger (1941:8) believed he could determine, with better than 90 percent accuracy, the number of whole pots represented by a collection of sherds of a given type, these sherds are described as representing 132 "fragmentary vessels." This suggests that this category might include many hundreds of sherds which Krieger had sorted into an appreciably smaller number of "pot lots." Not so. When I examined the Sanders site collections in 1995 I found 132 sherds in box containing the pottery Krieger had sorted as Canton Incised.

In a letter commenting on the manuscript just cited, James B. Griffin (1941:2) remarked: "Your handling of the sherds as vessels is an interesting one and is certainly the first presentation of the idea. It will be fun waiting the reaction." Unfortunately, Krieger and his students were never challenged on this misleading practice.

29.

They also added a whole pot (Suhm and Jelks 1962:Plate 12A) from the substantial collection of unassociated pots Jackson obtained during the general digging at Sanders, or from an unrecorded plowed out grave. The bowl shown in Plate $12 \mathrm{~A}$, specimen \#67 according to the TARL ceramic inventory for Sanders, is listed there as an unassociated specimen. Hence, they had no associational evidence for including carinated bowls like this one, or the incised design it bears, in the type description for Canton Incised. Hence, neither the carinated bowl form nor this design is attested for this "type" or for the Sanders mortuary assemblage. Unfortunately, the fact that this pot was among the unassociated specimens from Sanders is not mentioned in the type description, leaving the unwary and uncritical free to assume that it was part of the mortuary assemblage.

30.

Furthermore, I have since confirmed what I only suspected originally. Some of the so-called Sanders focus pottery from the graves at Sanders is shell tempered, as it should be since it is Spiro phase pottery. According to my observations of November 28, 1995 at the Texas Archeological Research Laboratory, verified by curator Darrell Creel, at least four pots from the graves at Sanders are shell tempered. That is, they contain particles of what appear, to the naked eye and under low power magnification, to be shell, and these effervesced when tested with dilute hydrochloric acid. These are: pot \# 358, a large, red slipped "Sanders Plain" bowl with a scalloped rim from burial 9; pot \# 361, a large, tan slipped "Sanders Plain" bowl with a scalloped rim from burial 9; pot \# 433, a small, strap-handled bowl from burial 17; and pot \# 520, a large, brown slipped "Sanders Plain" bowl from burial 20.

Two others are probably shell tempered. Pot \# 362, a Maxey Noded Redware bottle from burial 9 , is mostly covered with a heavy red slip, but small white particles were visible in a worn area on the lip. These effervesced like shell and I suspect they are shell. But, because of their small size, I could not be certain. My suspicion is that all Maxey Noded Redware bottles are tempered with fine ground shell but it usually goes unnoticed because the particles are very small and bottles of this type are characteristically heavily slipped. Pot \# 364, a 
small brown-slipped bowl also exhibited, in a few places where the slip had worn away, small white particles that looked and effervesced like shell.

Pot \# 515, a large, red-slipped Sanders Plain bowl from Burial 20 is "hole tempered," meaning it exhibits the small, flattish holes characteristic of a pot that has lost its shell temper due to leaching or over firing.

Finally, there is pot \#372a, a large, tan slipped, olla (Krieger 1946:Fig. 17) from burial B11 which is so obviously heavily tempered with shell that Krieger could not deny it. Instead, he (1946:197) argued that did not belong to the Sanders mortuary assemblage because part of it was found plowed out on the surface of the site. But part of it seems to have been found in burial B-11 (the TARL catalogue card gives its provenience as "Burial B-11") so that is its probable provenience, assuming that pots or pieces of pots are more likely to be plowed out of graves than into them. It is obviously a Bell Plain trade-piece from somewhere in the central Mississippi Valley, probably from the Walls phase in northwestern Mississippi (Griffin 1952:236, Fig. 127 I). 
Caddoan Archeology 